Linköping Studies in Science and Technology

Dissertation No. 1867

\title{
Photoluminescence Characteristics of III-Nitride Quantum Dots and Films
}

\author{
Martin Eriksson
}

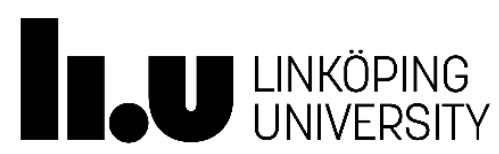

Semiconductor Materials

Department of Physics, Chemistry, and Biology Faculty of Science and Engineering

Linköping University, SE-581 83 Linköping, Sweden 
Cover: Optical microscope image of light transmitted through the apices of metallized GaN pyramids, with a microphotoluminescence spectrum recorded at $5 \mathrm{~K}$ of a single $\mathrm{GaN}$ pyramid, showing well-defined emission from a single InGaN quantum dot.

During the course of research underlying this thesis, Martin Eriksson was enrolled in Agora Materiae, a multidisciplinary doctoral program at Linköping University, Sweden.

(C) Martin Eriksson, 2017

Printed in Sweden by LiU-Tryck 2017

ISSN 0345-7524

ISBN 978-91-7685-487-7 


\section{Abstract}

III-Nitride semiconductors are very promising for both electronics and optical devices. The ability of the III-Nitride semiconductors as light emitters to span the electromagnetic spectrum from deep ultraviolet light, through the entire visible region, and into the infrared part of the spectrum, is an important feature, making this material essential for the field of light emitting devices. In fact, the blue emission from Indium Gallium Nitride (InGaN), which was awarded the 2014 Nobel Prize in Physics, is the basis of the common and important white light emitting diode (LED).

Quantum dots (QDs) have properties that make them very interesting for light emitting devices for a range of different applications, such as the possibility of increasing device efficiency. The spectrally well-defined emission from QDs also allows accurate color reproduction and highperformance communication devices. The small size of QDs, combined with selective area growth allows for an improved display resolution. By control of the polarization direction of the QDs, they can be used in more efficient displays as well as in traditional communication devices. The possibility of sending out entangled photon pairs is another QD property of importance for quantum key distribution used for secure communication.

QDs can hold different exciton complexes, such as the neutral single exciton, consisting of one electron and one hole, and the biexciton, consisting of two excitons. The integrated PL intensity of the biexciton exhibits a quadratic dependence with respect to the excitation power, as compared to the linear power dependence of the neutral single exciton. The lifetime of the neutral exciton is 880 ps, whereas the biexciton, consisting of twice the number of charge carriers and lacks a dark state, has a considerably shorter lifetime of only 500 ps. The ratio of the lifetimes is an indication that the size of the QD is on the order of the exciton Bohr radius of the InGaN crystal making up these QDs in the InGaN QW.

A large part of the studies of this thesis has been focused on InGaN QDs on top of hexagonal Gallium Nitride (GaN) pyramids, selectively grown by Metal Organic Chemical Vapor Deposition (MOCVD). On top of the GaN 
pyramids, an InGaN layer and a GaN capping layer were grown. From structural and optical investigations, InGaN QDs have been characterized as growing on (0001) facets on truncated GaN pyramids. These QDs exhibit both narrow photoluminescence linewidths and are linearly polarized in directions following the symmetry of the pyramids.

In this work, the neutral single exciton, and the more rarely observed negatively charged exciton, have been investigated. At low excitation power, the integrated intensity of the PL peak of the neutral exciton increases linearly with the excitation power. The negatively charged exciton, on the other hand, exhibits a quadratic power dependence, just like that of the biexciton. Upon increasing the temperature, the power dependence of the negatively charged exciton changes to linear, just like the neutral exciton. This change in power dependence is explained in terms of electrons in potential traps close to the QD escaping by thermal excitation, leading to a surplus of electrons in the vicinity of the QD. Consequently, only a single exciton needs to be created by photoexcitation in order to form a negatively charged exciton, while the extra electron is supplied into the QD by thermal excitation from the barriers.

Upon a close inspection of the PL of the neutral exciton, a splitting of the peak of just below $0.4 \mathrm{meV}$ is revealed. There is an observed competition in the integrated intensity between these two peaks, similar to that between an exciton and a biexciton. The high energy peak of this split exciton emission is explained in terms of a remotely charged exciton. This exciton state consists of a neutral single exciton in the QD with an extra electron or hole in close vicinity of the QD, which screens the built-in field in the QD.

The InGaN QDs are very small; estimated to be on the order of the exciton Bohr radius of the InGaN crystal, or even smaller. The lifetimes of the neutral exciton and the negatively charged exciton are approximately 320 ps and 130 ps, respectively. The ratio of the lifetimes supports the claim of the QD size being on the order of the exciton Bohr radius or smaller, as is further supported by power dependence results. Under the assumption of a spherical QD, theoretical calculations predict an emission energy shift 
of $0.7 \mathrm{meV}$, for a peak at $3.09 \mathrm{eV}$, due to the built-in field for a QD with a diameter of $1.3 \mathrm{~nm}$, in agreement with the experimental observations.

Studies of the InGaN QD PL from neutral and charged excitons at elevated temperatures ( $4 \mathrm{~K}$ to $166 \mathrm{~K}$ ) has revealed that the QDs are surrounded by potential fluctuations that trap charge carriers with an energy of around $20 \mathrm{meV}$, to be compared with the exciton trapping energy in the QDs of approximately $50 \mathrm{meV}$. The confinement of electrons close to the QD is predicted to be smaller than for holes, which accounts for the negative charge of the charged exciton, and for the higher probability of capturing free electrons. We have estimated the lifetimes of free electrons and holes in the GaN barrier to be 45 ps and 60 ps, respectively, in consistence with excitons forming quickly in the barrier upon photoexcitation and that free electrons and holes get trapped quickly in local potential traps close to the QDs. This analysis also indicates that there is a probability of $35 \%$ to have an electron trapped in the QD between the photoexcitation pulses, in agreement with a lower than quadratic power dependence of the negatively charged exciton.

InN is an attractive material due to its smaller band gap energy with an associated infrared emission, for applications such as light emitters for communication purposes. However, it is more difficult to grow with high quality and low doping concentration as compared to GaN. QDs with a higher In-composition or even pure $\ln \mathrm{N}$ is an interesting prospect as being a route towards increased quantum confinement and room temperature device operation. For all optical devices, p-type doping is needed. Even nominally undoped InN samples tend to be heavily n-type doped, causing problems to make pn-junctions as needed for LEDs. In our work, we present $\mathrm{Mg}$-doped $\mathrm{p}$-type $\mathrm{InN}$ films, which revert to $\mathrm{n}$-type conductivity when increasing the Mg-concentration further. We have focused on the effect of the Mg-doping on the light emission properties of these films. The low Mg-doped InN film is inhomogeneous and is observed to contain areas with n-type conductivity, so called n-type pockets in the otherwise $\mathrm{p}$-type $\operatorname{lnN}$ film. A higher concentration of $\mathrm{Mg}$ results in a higher crystalline quality and the disappearance of the n-type pockets. The high crystalline quality has enabled us to determine the binding energy of the $\mathrm{Mg}$ dopants to $64 \mathrm{meV}$. Upon further increase of the Mg concentration, the film reverts to $\mathrm{n}$-type conductivity. The highly $\mathrm{Mg}$ doped sample also 
exhibits a red-shifted emission with features that are interpreted as originating from Zinc-Blende inclusions in the Wurtzite InN crystal, acting as quantum wells. The $\mathrm{Mg}$ doping is an important factor in controlling the conductivity of $\operatorname{lnN}$, as well as its light emission properties, and ultimately develop InN-based devices.

In summary, in this thesis, both pyramidal InGaN QDs and InGaN QDs in a QW have been investigated. Novel discoveries of exciton complexes in these QD systems have been reported. Novel knowledge has also been gained about the challenging $\ln N$ material, including a study of the effect of the Mg-doping concentration on the semiconductor crystalline quality and its light emission properties. The outcome of this thesis enriches the knowledge of the III-Nitride semiconductor community, with the longterm objective to improve the device performance of III-Nitride based light emitting devices. 


\section{Populärvetenskaplig sammanfattning}

Halvledarmaterial baserade på III-nitrider är viktiga för applikationer inom såväl elektronik som optoelektronik. Mest närliggande denna avhandling ligger användningsområden inom optoelektronik. Genom att blanda GaN och InN kan man skapa ljuskällor som emitterar ljus hela vägen från ultravioletta delen av det elektromagnetiska spektrumet till det infraröda spektrala området. Utöver dessa material så kan AIN användas för att nå djupare in i det ultravioletta spektrala området. Denna möjlighet att variera materialets komposition och således skräddarsy det emitterade ljusets våglängd (färg) gör detta halvledarmaterial mycket intressant för ljuskällor, så som lysdioder (LED). Materialet InGaN (en blandning av GaN och InN) är så pass viktigt att Isamu Akasaki, Hiroshi Amano och Shuji Nakamura tilldelades Nobelpriset i fysik 2014 för den effektiva blåa InGaN-baserade lysdioden som har legat till grund för dagens effektiva vita lysdioder. Den vita lysdioden har blivit en del av vår vardag de senaste åren, med användningsområden såsom belysning, bilar och bildskärmar. Trots framgången för vita lysdioder så finns det fortfarande mycket utrymme för förbättringar.

Ett fokus i denna avhandling är att förbättra vår kunskap om kvantprickar i materialet InGaN. Kvantprickar är nanometer-små kristaller, som kan ha många olika former. De InGaN-kvantprickar som vi studerat är asymmetriska. Atomerna som bygger upp kvantprickarna är bara en storleksordning mindre än själva kvantpricken i dess tunnaste riktning. Dessa kvantprickar har flera speciella ljusegenskaper. En karakteristisk egenskap är att man kan reglera våglängden genom att ändra kvantprickens storlek. En stor kvantprick emitterar ljus med längre våglängd, det vill säga mer åt det röda hållet. Vice versa så leder en minskande storlek på kvantpricken till kortare våglängd och ljus mer åt blått. Lägre In-komposition leder också till en blåförskjutning, samt högre In-komposition till en rödförskjutning av emissionen. En annan viktig egenskap är att emissionen från kvantprickarna är linjärpolariserad. Kvantprickarna är växta på toppen av mikrometerstora hexagonala pyramider i GaN, där det finns en korrelation mellan emissionens polarisationsriktning och pyramidens hexagonala struktur. Detta är viktigt i flera avseenden, såsom för ljuskällor i bildskärmar så väl som i kommunikationsutrustning. 
Kvantprickar attraherar laddningsbärare, såväl negativa elektroner som positiva hål. Ett hål är en avsaknad av en elektron och kan ses som en positiv laddningsbärare. Laddningstillståndet i kvantpricken avgör både våglängden för det emitterade ljuset och tiden som de befinner sig $\mathrm{i}$ kvantpricken innan de rekombinerar (försvinner från kvantpricken) och ljus emitteras. Sannolikheten att kvantpricken befinner sig i ett specifikt laddningstillstånd varierar från tillstånd till tillstånd och kan ses som en variation i intensiteten på det emitterade ljuset. Det mest vanligt förekommande tillståndet är en neutral exciton, bestående av en negativ och en positiv laddning. Även biexcitoner (två excitoner i kvantpricken) och negativt laddade excitoner (två negativa laddningar och en positiv laddning) har studerats. Från studierna har vi kunnat dra slutsatsen att den extra laddningen hos den negativt laddade excitonen reducerar inverkan av elektriska fält kring kvantpricken, vilket gör att tillståndet har en stabilare emissionsvåglängd. Fler laddningsbärare i kvantpricken resulterar $\mathrm{i}$ en kortare livstid för tillståndet innan laddningsbärarna rekombinerar och skickar ut ljus.

Kvantprickarna som har studerats har en uppskattad storlek på endast ungefär en nanometer i sin minsta dimension. Detta leder till att det emitterade ljuset har en stabil våglängd, såväl som en kort livstid för laddningsbärarna i kvantpricken, vilka båda är viktiga för lysdiodapplikationer. För dessa applikationer krävs en grundlig förståelse för hur hårt bundna laddningsbärarna är i kvantprickarna. Våra studier visar på två viktiga energier för bindningen av laddningsbärare $i$ kvantprickarna. Laddningsbärare i närheten av kvantpricken är bundna med ungefär $20 \mathrm{meV}$, vilket innebär att dessa kan exciteras och fångas in av kvantpricken genom att värma provet till minst $40 \mathrm{~K}$ och således leda till en starkare emission från kvantpricken. I kvantpricken är de hårdare bundna, med en energi på ungefär $50 \mathrm{meV}$, vilket innebär att om provet värms till över $80 \mathrm{~K}$ så minskar intensiteten på det emitterade ljuset drastiskt, då laddningsbärarna termiskt exciteras ut ur kvantpricken. Denna förståelse är viktig för framtida applikationer där ljusemission vid rumstemperatur krävs.

InN är också ett intressant material med avseende på dess optiska egenskaper. Genom att dopa det med Mg kan man skapa domäner som domineras av positiva fria laddningar, som tillsammans med en nominellt 
odopad InN-film eller Si-dopad InN-film med dominerande negativa laddningsbärare kan användas för att skapa lysdioder som emitterar i den infraröda delen av det elektromagnetiska spektrumet. En stark påverkan av Mg-dopningen på InN-filmers ljusegenskaper har observerats. Vid låga dopkoncentrationer av $\mathrm{Mg}$ så skapas inhomogena domäner i InN-filmen, som våra studier indikerar kommer från domäner där det finns en majoritet med negativa fria laddningsbärare inbakade i en större domän, som domineras av positiva fria laddningsbärare. Högre Mgdopkoncentration leder till ett mer homogent prov, och därmed en mer väldefinierad och starkare emission, vilka är viktiga egenskaper för LEDapplikationer. EN ännu högre koncentration av Mg-dopning leder till att provet återgår till en majoritet med negativa fria laddningsbärare och att emissionen rödförskjuts ännu längre in i det infraröda området och tappar i ljusstyrka. Detta kan delvis kopplas till ökande antal staplingsfel, det vill säga regioner där atomlagren staplats med en annan sekvens.

Denna avhandling täcker både pyramidala InGaN-kvantprickar och InGaNkvantprickar i kvantbrunnar. Nya upptäckter av laddningstillstånd i kvantprickarna har lett till en bättre förståelse för hur kvantprickarna uppför sig, speciellt med avseende på deras optiska egenskaper. Avhandlingen inkluderar även utökad kunskap om det viktiga materialet InN för applikationer såsom ljusemitterare inom det infraröda området. Här har påverkan av $\mathrm{Mg}$-dopningen på InN-filmernas ljusegenskaper studerats. Dessa studier kompletterar varandra och ger en djupare förståelse kring III-nitriderna med avseende på deras optiska egenskaper, samtidigt som steg har tagits mot att förbättra prestandan hos IIInitridbaserade ljuskällor. 


\section{Acknowledgement}

I would like to thank all my colleagues, friends, and family who have supported me during my years as a PhD student. I have had the pleasure to get to know so many wonderful people, and I have enjoyed a lot of fruitful discussions and support from them. There are some people in particular who I would like to mention.

Per Olof Holtz, thank you so much for being my main supervisor and giving me the opportunity to do my Ph.D. thesis together with you. You have shared so much of your wisdom and knowledge and always been more supportive than I could ever hope for. Thank you for always being available for discussions, even when you have been busy or out of office. I am also eternally grateful for all the different opportunities that you have given me, and the collaborations that you have made possible.

Fredrik Karlsson, thank you very much for being my co-supervisor, and for sharing your knowledge with me and assisting me in the lab, as well as with physics related questions and MATLAB, and for the many interesting and fruitful discussions.

Peder Bergman, thank you very much for being my co-supervisor, and for teaching me about time resolved photoluminescence spectroscopy and assisting me in the lab with your deep knowledge and experience.

Volodymyr Khranovskyy, thank you very much for being my co-supervisor, and for all of our collaborations on $\mathrm{ZnO}$. I would also like to give special thanks for all the collaborations that you have made possible for me and for being very supportive in so many ways.

Jordi Altimiras, thank you for being my mentor and for the interesting discussions we have had.

Chih-Wei Hsu, thank you so much for taking me on as your apprentice when I arrived. Since that day, you have taught me so much and still are, as I follow you once more, moving into growth. Thank you for all the samples that you have provided me with. I also want to give my great gratitude for all of your support and being available for assistance whenever I have needed it. 
Anders Lundskog, thank you for all the samples you have provided me with, and the great knowledge about growth of III-nitrides that you have shared with me.

Galia Pozina, thank you for all your assistance within time resolved photoluminescence spectroscopy, and in particular for teaching me and assisting me with cathodoluminescence spectroscopy. I also highly value our discussions and the knowledge that you have shared with me.

Vanya Darakchieva and Bo Monemar, thank you so much for all the support and for sharing your vast knowledge about III-nitride materials with me. I would also like to thank you for your collaboration with me on our InN investigations.

Houssaine Machhadani, thank you very much for all of your assistance, joint measurements, and all of your great post-processing work, which I am very happy that you introduced me to. Thank you for all the great photon correlation results that have supported my own studies. I also value all of our discussions a lot.

Supaluck Amloy, thank you for all your support and our collaborations on InGaN quantum dot investigations.

Sergey Khromov, thank you for all your support and the collaboration we have had on the InN investigations.

Justinas Palisaitis, thank you for all of the transmission electron microscopy investigations and fruitful discussions that we have had.

Evgenii Moskalenko, thank you for your assistance in the lab and for all the fruitful discussions.

Plamen Paskov, thank you for all the great knowledge that you have shared with me, in particular on III-nitride semiconductors and photoluminescence spectroscopy.

Erik Janzén, thank you for sharing your wisdom with me and for all of your valuable support.

Ivan Ivanov, thank you for all the support in the lab, and in particular for sharing your great knowledge about spectrometers, lasers, and cryostats with me. 
Tomas Jemsson, thank you for all support and interesting conversations, and for all the great photon correlation results that have supported my own studies.

Roger Carmesten, Sven Andersson, and Arne Eklund thank you for all the great technical assistance in the lab and the continuous supply of liquid helium.

Jr-Tai Chen, thank you for always supporting and believing in me, and for sharing your great knowledge about growth of III-nitrides with me. Thank you very much for giving me the opportunity to work together and for your understanding in the last stage of my Ph.D. studies.

Olof Kordina, thank you for your support and understanding, in particular during the late stage of my Ph.D. studies.

Daniel Nilsson, Yuttapoom Puttisong, and Shula Chen, thank you for your support and all the interesting and fruitful discussions over the years.

Valdas Jokubavicius, thank you for your assistance and for the SiC sample. Ildiko Farkas, thank you for your support with the dicing.

Seung-Hyuk Lim, thank you for taking over a lot of the responsibilities in the lab during my final writing stage, giving me an ease of mind.

I would like to thank all of my many more collaborators that I have had over the years.

I also want to thank all of my friends, who have given me great support and have always been there for me.

Finally, I would like to share my great gratitude towards my family, and in particular my parents, who not only have been very supportive during my time as a Ph.D. student, but have raised me and supported me throughout my life, and always encouraging me in my interests. You have taught me so much, and given me incredible opportunities. Without you, I would not be where I am today. Thank you! 


\section{Contents}

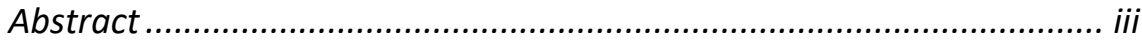

Populärvetenskaplig sammanfattning ................................................ vii

Acknowledgement..............................................................................

Part I: Introduction to the Research Field ..........................................1

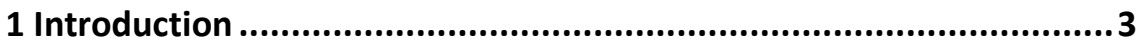

2 Electronic and Optical Properties of Semiconductors .........................5

2.1 Energy Bands and Energy Levels ................................................... 5

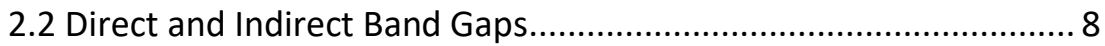

2.3 Free-to-Bound Transitions and Exciton Recombination ................. 9

2.4 Charge Carrier Injection and Recombination ............................... 11

3 Quantum Structures ..................................................................... 13

3.1 Quantum Confinement and Quantum Wells .............................. 13

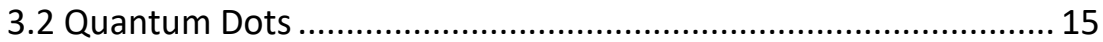

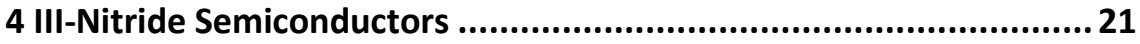

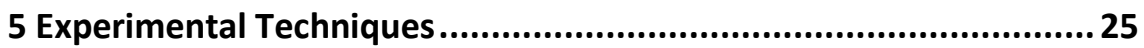

5.1 Metal Organic Chemical Vapor Deposition .................................. 25

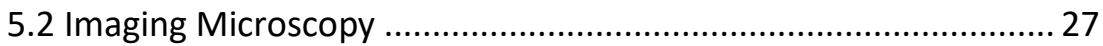

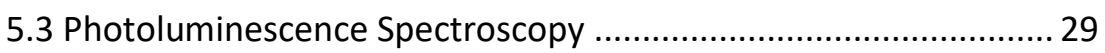

5.4 Steady State Micro-Photoluminescence Spectroscopy.................. 32

5.5 Time Resolved Micro-Photoluminescence Spectroscopy ............. 33

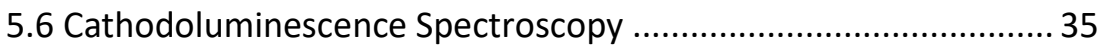

5.7 Enhancing Light Emission Quality of Quantum Dots ..................... 38

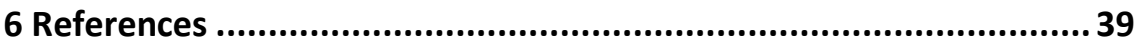

7 List of Publications......................................................................... 41

7.1 Papers Included in the Thesis ...................................................... 41

7.2 Papers Not Included in the Thesis ................................................ 43 
Part II: Papers ................................................................ 47 
Part I: Introduction to the Research Field 


\section{Introduction}

Part 1 of this thesis serves as an introduction to the field of research presented in the papers in Part 2 of the thesis. This thesis is focused on the photoluminescence (light emission) properties of III-nitride quantum dots and films. Light emitting devices based on III-nitride semiconductors have great potentials in many areas, the most well-known being public lighting. In 2014, Isamu Akasaki, Hiroshi Amano, and Shuji Nakamura were awarded the Nobel Prize in Physics for the invention of efficient blue light emitting diodes (LEDs), which has led to the construction of efficient white LEDs. These are the white LEDs seen all around us today, for general illumination, displays, indicators, and much more. The basis for these light sources is the semiconductor Indium Gallium Nitride (InGaN), which emits blue light. The blue light is partly absorbed by a phosphor that emits yellow light, and the combination of the blue and the yellow light creates the resulting light that we perceive as white. Even though InGaN has had great success in light emitting devices lately, there is still much to explore, and improvements to be made. For this, a deeper understanding of the fundamental physics of the active material in the light emitting device is crucial. This thesis addresses the light emission characteristics of IIInitride based quantum dots and films from a materials physics point of view.

The main focus of this thesis is the photoluminescence characteristics of InGaN pyramidal quantum dots, discussed in papers 1 and $3-6$. These quantum dots have a set of characteristics that make them very interesting both for fundamental research and for optoelectronic devices, 
namely: selective growth (spatial positioning of the quantum dots), spectrally well-defined emission (pure color), linearly polarized emission, limited effect by built-in fields, high recombination rate (quick response and high intensity), as well as being sources of single photons (useful for optical communication). InGaN quantum dots in InGaN quantum wells have also been investigated, with the results presented in paper 2 . Different exciton complexes, consisting of neutral excitons, biexcitons, and charged excitons have been studied in these two quantum dot systems, making them complementary to each other. Knowing the behavior of the excitons in these quantum dots, and the general light emitting properties of the quantum dots are of vital importance for the advance in the field of III-nitride quantum dots and in the development of improved light emitting devices based on these quantum dots.

In order to take the step from photoluminescence investigations in research labs to commercially available electrically driven light emitting diodes (LEDs) based on these quantum dots, $\mathrm{n}$ - and p-type doping is needed, the latter being considerably more difficult to accomplish. $\mathrm{Mg}$ is the best known acceptor (p-type dopant) for the III-nitrides today, and its effects on the light emission properties of $\ln \mathrm{N}$ films are presented in paper 7. 


\section{Electronic and Optical Properties of Semiconductors}

\subsection{Energy Bands and Energy Levels}

A semiconductor is often referred to as a material that has semi-good electrical and heat conductivity, in between a metal and an insulator. A semiconductor is more complicated than this and can in fact have as high conductivity as a metal and as low as an insulator. A semiconductor has two defining traits: properties like conductivity and charge carrier densities can be modified through doping, and it has an energy band gap between the conduction band and the valence band that spans all values of the wave vector. Semiconductors are made up of atoms that are arranged in a well-ordered lattice, referred to as a crystal. The valence electrons (electrons in outer shell of the atoms) take part in the covalent bonds that hold the crystal together. In their ground state, these valence electrons are situated in the valence band of the semiconductor. Given the right amount of energy, valence electrons can be excited to the next energy band above the valence band, which is called the conduction band (see Figure 2.1). Electrons in the conduction band move freely between the atoms in the crystal, and contribute to electrical conduction. Between the valence band and the conduction band, there are no energy states available for electrons in an intrinsic semiconductor, and this gap is called the band gap. The band gap energy, $E_{G}$, denotes the difference in energy between the bottom of the conduction band and the top of the valence band. For an intrinsic semiconductor at $0 \mathrm{~K}$, the valence band is filled with 
electrons and the conduction band is completely empty without exciting the sample.

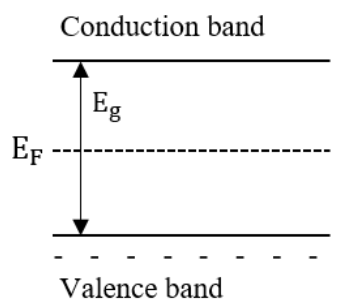

Figure 2.1: Energy band structure of an intrinsic semiconductor. $E_{g}$ is the band gap energy and $\mathrm{E}_{\mathrm{F}}$ is the Fermi energy.

The stacking sequence of the atoms making up the semiconductor lattice strongly affects the electrical and optical properties of the material, including the energy band gap. Two semiconductor crystals consisting of the same elements, but with different stacking sequences are defined as different polytypes of the material.

When an electron is excited from the valence band to the conduction band, it leaves an unoccupied electron state behind it. This is felt by neighboring valence electrons, which may move into this empty position, effectively moving the empty state, or absence of electron to the neighboring position from which the electron came from. This absence of an electron is denoted a hole, and behaves like a positively charged electron, albeit with a heavier effective mass. By the process of valence electrons moving into the electron vacancies, the hole effectively moves across the crystal lattice, in much the same way as electrons move across the crystal lattice by using the conduction band. Holes behave in the opposite way to electrons in all respects. This includes energies; electrons relax downwards, towards the valence band, whereas holes relax upwards, towards the conduction band. After a characteristic lifetime, an electron that has been excited to the conduction band will try to recombine with a hole in the valence band, and by doing so, releasing its energy in the form of a photon (quantum of light). This relaxation process is called radiative recombination. The excited electron can also relax without emitting a photon, called nonradiative recombination, such as when phonons (lattice vibrations) are emitted instead. 
The Fermi energy, $\mathrm{E}_{\mathrm{F}}$, is the energy position at which there is a $50 \%$ probability of having electron occupation, assuming there are energy levels present for the electrons to occupy. For semiconductors at a temperature of $0 \mathrm{~K}$, the Fermi energy is the position up to which the electrons occupy energy states, with no electrons present above this Fermi energy. The Fermi energy can be changed by doping. Doping the semiconductor with donors (n-type doping) results in donor energy levels inside the band gap just below the conduction band, which up-shifts the Fermi energy towards the conduction band and the donor energy level. These donors can donate their extra electron to the conduction band, and by doing so forming a surplus of free electrons, which become the majority carriers, making the holes the minority carriers. Similarly, by doping with acceptors (p-type doping), acceptor energy levels form inside the band gap just above the valence band. Each acceptor can accept one extra electron, because one is missing to form the needed covalent bond with its neighboring atoms. By accepting an electron, this effectively creates a hole in the valence band. Doping with acceptors therefore forms a surplus of free holes, which become the majority charge carrier, making the electrons the minority carriers.

The temperature of the semiconductor has significant effects on its properties. For instance, by increasing the temperature, the lattice vibrations increase, leading to a larger effective distance between the atoms, which reduces the band gap energy. Increasing the temperature above $0 \mathrm{~K}$ can also lead to ionization of donors and acceptors, which increases the charge carrier densities, and therefore the conductivity of the material. However, high temperatures may also prevent certain states from being populated, such as quantum dots, and therefore quenching the light emission related to these states. 


\subsection{Direct and Indirect Band Gaps}

There are actually more energy bands in semiconductor crystals than just the valence band and the conduction band, but are often only of academic importance, as electrons and holes usually just transfer between the conduction band and the valence band. The valence band can actually be divided into three bands; the heavy-hole band, the light-hole band, and the split-off band. The terms heavy- and light-hole bands are originating from the fact that the holes in these bands have effective masses that are higher in the heavy-hole band than in the light-hole band. The effective mass has an inverse relationship to the second derivate of the energy with respect to the wave vector, $k$.

The energies of the bands depend on the momenta of the electrons. Figure 2.2 depicts this energy dispersion with momentum. The momentum, $p$, depends on Planck's constant, $h$, and the wave vector, $k$, and is given by equation (2.1).

$$
p=h k
$$

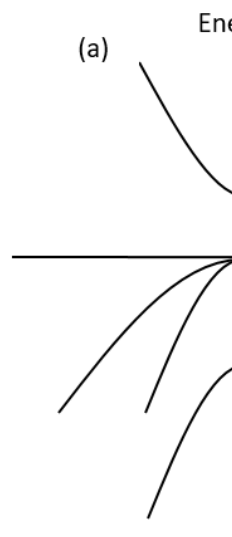

Energy
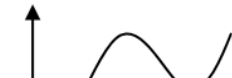

(b)

\section{Energy}

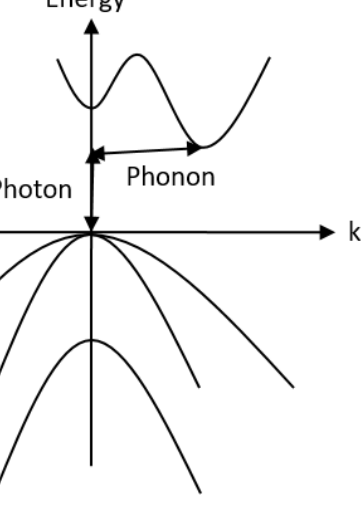

Figure 2.2: Energy dispersion graphs for semiconductors with direct and indirect band gaps. The axis denoted $\mathrm{k}$ is the wave vector.

Semiconductors are classified as having a direct band gap, or an indirect band gap, which are depicted in Figure 2.2. For a direct band gap semiconductor, like GaAs and GaN, the bottom of the conduction band and the top of the valence band occur at the same value in momentum 
space, whereas for an indirect band gap semiconductor, they occur at different positions in momentum space. As an electron at the conduction band minimum in a direct band gap semiconductor recombines with a hole at the valence band maximum, a photon is emitted, with an energy corresponding to the difference in energy between the electron and the hole prior to the recombination. This process is very fast and efficient, leading to potentially high intensity of the light emitted from the semiconductor, with a quick response time (light emitted shortly after that excited electrons and holes are formed). For an indirect band-gap semiconductor, like $\mathrm{Si}$ and $\mathrm{Ge}$, the recombination process is considerably slower, because the electron at the bottom of the conduction band and the hole at the top of the conduction band have different momenta. Both momentum and energy needs to be conserved for both excitation and recombination processes. In order for the electron and the hole to recombine, one or more phonons (particles with high momentum and low energy) need to be emitted or absorbed at the same time as a photon (particle with high energy and low momentum) is emitted, which is a much slower process than just emitting a photon. These properties make direct band gap semiconductors important for light emitting devices, whereas for devices that absorb light, such as solar cells, an indirect band gap semiconductor has the benefit that the free electrons and holes created upon absorption of photons survive in the conduction band and valence band, respectively, for a longer time, giving more time for harvesting the charge carriers in an electric circuit. The energy of a photon is given by Planck's constant and the frequency of the light:

$$
E_{\text {photon }}=h v
$$

\subsection{Free-to-Bound Transitions and Exciton Recombination}

When electrons and holes recombine, only the recombination of free electrons and free holes have been considered so far. The recombination of free charge carriers is, however, generally not the most common recombination process, due to the fact that electrons and holes are usually trapped at shallow or deep energy levels inside the band gap. These energy levels may originate from donor- or acceptor-like dopants or crystal defects, for example. It is possible for a free electron to 
recombine with a hole on an acceptor, as well as for an electron on a donor to recombine with a free hole, so called free-to-bound transitions. The energy of the photon of such a recombination process is lower compared to the recombination of free charge carriers by an amount corresponding to the binding energy of the donor or acceptor, which is the energy needed to ionize the dopant.

Electrons and holes have opposite charge, which results in Coulomb attraction and the possibility of forming and exciton, which is a bound state consisting of an electron and a hole that move together in the crystal, as a single particle. When the electron and the hole in the exciton recombine, the emitted photon has an energy that is smaller than the energy of a photon emitted by the recombination of a free electron and a free hole. This energy difference is referred to as the exciton binding energy, which is the energy needed in order to break the exciton apart.

Different types of excitons exist, with three common excitons found in bulk (no quantum confinement) semiconductors shown in Figure 2.3. The free exciton is simply an electron-hole pair that moves around freely in the lattice. The exciton can also bind to donors or acceptors in the lattice, and in doing so forming donor bound or acceptor bound excitons. The emission of a photon when a bound exciton recombines is even lower than for the free exciton, because of the additional binding to the dopant atom.

a)

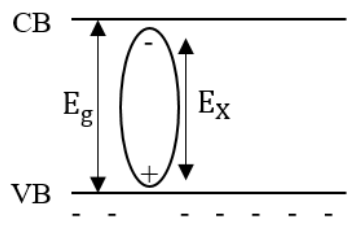

b)

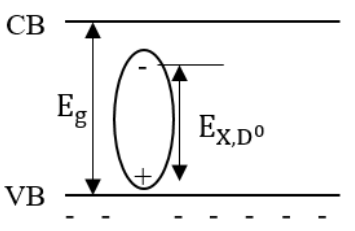

c)

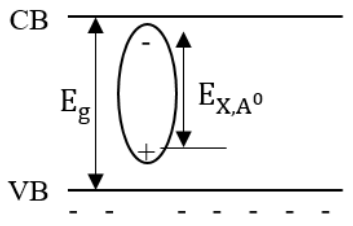

Figure 2.3: Excitons in bulk semiconductors: (a) free exciton, (b) donor-bound exciton, and (c) acceptor-bound exciton.

Many more excitonic states are possible, in particular in quantum dots. Some important excitonic states in quantum dots are the neutral exciton, the biexciton, and the negatively and positively charged excitons, which are discussed in section 3.2. 


\subsection{Charge Carrier Injection and Recombination}

Consider an n-type semiconductor, where $\mathrm{n}_{0} \gg \mathrm{p}_{0}\left(\mathrm{n}_{0}\right.$ and $\mathrm{p}_{0}$ are the electron and hole concentrations, respectively, under no illumination (excitation)). Under a certain illumination intensity, the charge carrier concentrations will increase by $\Delta \mathrm{n}=\mathrm{n}-\mathrm{n}_{0}$ and $\Delta \mathrm{p}=\mathrm{p}-\mathrm{p}_{0}$ for electrons and holes, respectively. In this n-type semiconductor, it is possible even at moderate illumination intensities that $\mathrm{n}_{0} \gg \Delta \mathrm{n}=\Delta \mathrm{p} \gg$ $\mathrm{p}_{0}$, where the equal sign is valid when there is no recombination with impurities or trapped carriers. The relative increase of holes (minority carriers) is quite high, whereas the relative increase of electrons is quite low $\left(\frac{\Delta p}{p_{0}} \gg \frac{\Delta n}{n_{0}}\right)$, and this process is therefore called minority carrier injection.

Assuming not too large charge carrier densities, $\mathrm{n}$ and $\mathrm{p}$, the total recombination rate $\mathrm{R}^{\prime}$ can be written: ${ }^{1}$

$$
\mathrm{R}^{\prime}=\operatorname{Cnp}=\mathrm{C}\left(\mathrm{n}_{0}+\Delta \mathrm{n}\right)\left(\mathrm{p}_{0}+\Delta \mathrm{p}\right)
$$

$C$ is a factor of proportionality. At equilibrium $(\Delta n=\Delta p=0)$, there is only thermal recombination, the rate of which can be written $\mathrm{Cn}_{0} \mathrm{p}_{0}$. By subtracting this term from the total recombination, the recombination due to injection of charge carriers is obtained:

$$
\mathrm{R}=\mathrm{C}\left(\left(\mathrm{n}_{0}+\Delta \mathrm{n}\right)\left(\mathrm{p}_{0}+\Delta \mathrm{p}\right)-\mathrm{n}_{0} \mathrm{p}_{0}\right) \approx \mathrm{C}\left(\mathrm{n}_{0} \Delta \mathrm{p}+\mathrm{p}_{0} \Delta \mathrm{n}\right)
$$

This is a good approximation when the injection of carriers is much lower than the majority carrier density. For $\Delta \mathrm{n} \approx \Delta \mathrm{p}$ in an $\mathrm{n}$-type semiconductor (the III-nitrides are usually $n$-type), then $\mathrm{n}_{0} \Delta \mathrm{p} \gg \mathrm{p}_{0} \Delta \mathrm{n}$ and:

$$
\mathrm{R} \approx \mathrm{Cn}_{0} \Delta \mathrm{p}
$$

Similarly, in a $\mathrm{p}$-type semiconductor for $\Delta \mathrm{n} \approx \Delta \mathrm{p}$, then $\mathrm{p}_{0} \Delta \mathrm{n} \gg \mathrm{n}_{0} \Delta \mathrm{p}$ and:

$$
\mathrm{R} \approx \mathrm{Cp}_{0} \Delta \mathrm{n}
$$

In other words, the recombination rate is proportional to the density of excess minority carriers due to injection. The density of excess minority carriers if the light source exciting the semiconductor is turned off at $t=0$ can be expressed as an exponential decay. 


$$
\Delta \mathrm{p}(\mathrm{t})=\Delta \mathrm{p}(0) \mathrm{e}^{-\frac{\mathrm{t}}{\tau_{\mathrm{p}}}}
$$

The decay parameter $\tau_{p}$ is called the lifetime of excess holes (hole minority carrier lifetime). The recombination rate can be written as follows:

$$
\mathrm{R}=-\frac{\mathrm{d} \Delta \mathrm{p}(\mathrm{t})}{\mathrm{dt}}=\frac{\Delta \mathrm{p}(0)}{\tau_{\mathrm{p}}} \mathrm{e}^{-\frac{\mathrm{t}}{\tau_{\mathrm{p}}}}=\frac{\Delta \mathrm{p}(\mathrm{t})}{\tau_{\mathrm{p}}}
$$

Comparing equations 2.5 and 2.8 , it can be seen that the hole minority carrier lifetime can be written as follows:

$$
\tau_{\mathrm{p}}=\frac{1}{\mathrm{Cn}_{0}}
$$

Similarly, for a p-type semiconductor, the rate of recombination and electron minority lifetime are:

$$
\begin{aligned}
& \mathrm{R}=\frac{\Delta \mathrm{n}(\mathrm{t})}{\tau_{\mathrm{n}}} \\
& \tau_{\mathrm{n}}=\frac{1}{\mathrm{Cp}_{0}}
\end{aligned}
$$




\section{Quantum Structures}

\subsection{Quantum Confinement and Quantum Wells}

In an intrinsic bulk semiconductor, the electrons in the conduction band and the holes in the valence band are generally allowed to move freely in all three dimensions, and the same is true for free excitons. If a semiconductor with lower band gap is sandwiched between two semiconductors with larger band gaps and lower electron affinities, and the semiconductor with a smaller band gap is thin enough, usually a few to tens of nanometers (order of the Bohr radius), the charge carriers in this layer are confined in one dimension, meaning they can only move within the layer, called a quantum well (QW). This so-called quantum confinement creates energy levels (states) for electrons and holes above the conduction band edge and below the valence band edge, respectively, as shown in figure 3.1. If the quantum well thickness is increased too much, the quantum confinement is lost, and it regains its bulk properties.

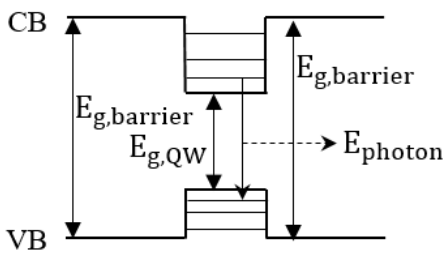

Figure 3.1: Energy band diagram of a quantum well. 
The excitons in the QW undergoing radiative recombination will send out light with an energy equal to the band gap energy of the QW material, plus the energy from the conduction band edge to the occupied electron state, plus the energy from the valence band edge to the occupied hole state, minus the exciton binding energy. Assuming that only the ground state in the QW is populated, the energy of the emitted photon is given by equation 3.1 :

$$
E_{P L}=E_{g, Q W}+E_{e 1}+E_{h 1}-E_{X, b}
$$

In a quantum wire (QWR), the charge carriers are confined in two dimensions, which mean that they can only move along the wire, in one dimension. If the charge carriers are confined in all three dimensions of space, this semiconductor structure is called a quantum dot (QD). See Figure 3.2 for a schematic diagram of these three quantum structures.
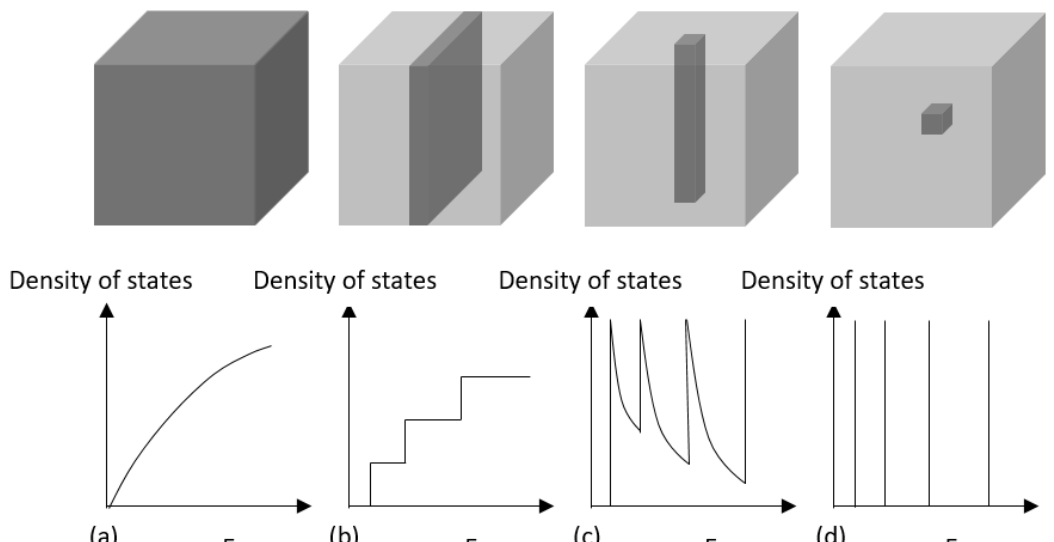

sity of states

Density of states

Density of states

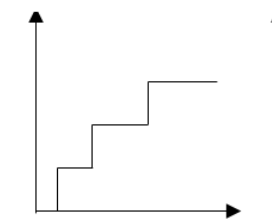

(b)

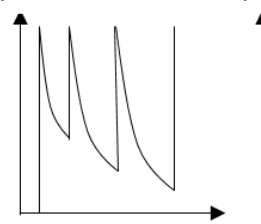

(c)

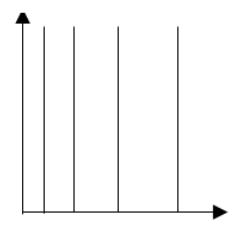

(d)

Energy

Figure 3.2: Schematic drawings and graphs of the density of states as functions of energy for (a) bulk semiconductor, (b) quantum well, (c) quantum wire, and (d) quantum dot.

Electrons and holes in the conduction band and the valence band, respectively, occupy electronic states. The density of these states with respect to energy determine the density of charge carriers, or number of charge carriers if the volume is known, in the semiconductor. The density of states together with the band gap energy tell us how high energy that is needed in order to populate available states with charge carriers, and 
ultimately how much the semiconductor can be excited before filling up all of the available states. The density of states strongly depends on the quantum confinement, as depicted in Figure 3.2, where it changes from a continuum of states for bulk (no quantum confinement) to discrete states for a quantum dot (three-dimensional confinement). The density of states can be described by the following equations, where $N$ is the number of states, $E$ is the energy of the charge carrier, $\varepsilon_{\mathrm{i}}$ is the eigenenergy of the state, $\Theta$ is the Heaviside step function, and $\delta$ is the Dirac delta function.

$$
\begin{aligned}
& \text { Bulk: } \frac{\mathrm{dN}}{\mathrm{dE}} \propto \frac{\mathrm{d}}{\mathrm{dE}} \mathrm{E}^{\frac{3}{2}} \propto \mathrm{E}^{\frac{1}{2}} \\
& \text { QW: } \frac{\mathrm{dN}}{\mathrm{dE}} \propto \frac{\mathrm{d}}{\mathrm{dE}} \sum_{\epsilon_{\mathrm{i}}<\mathrm{E}}\left(\mathrm{E}-\varepsilon_{\mathrm{i}}\right)=\sum_{\epsilon_{\mathrm{i}}<\mathrm{E}} 1 \\
& \text { QWR: } \frac{\mathrm{dN}}{\mathrm{dE}} \propto \frac{\mathrm{d}}{\mathrm{dE}} \sum_{\epsilon_{\mathrm{i}}<\mathrm{E}}\left(\mathrm{E}-\varepsilon_{\mathrm{i}}\right)^{\frac{1}{2}} \propto \sum_{\epsilon_{\mathrm{i}}<\mathrm{E}}\left(\mathrm{E}-\varepsilon_{\mathrm{i}}\right)^{-\frac{1}{2}} \\
& \text { QD: } \frac{\mathrm{dN}}{\mathrm{dE}} \propto \frac{\mathrm{d}}{\mathrm{dE}} \sum_{\epsilon_{\mathrm{i}}<\mathrm{E}} \Theta\left(E-\varepsilon_{\mathrm{i}}\right)=\sum_{\epsilon_{\mathrm{i}}} \delta\left(E-\varepsilon_{\mathrm{i}}\right)
\end{aligned}
$$

\subsection{Quantum Dots}

A quantum dot (QD) is a nanometer-sized semiconductor enclosed within a semiconductor with a larger band gap energy and lower electron affinity, yielding discrete energy states for the electrons and holes in the $Q D$, as described earlier. Due to the discrete energy states, when an electron recombines with a hole, a photon with a well-defined energy is emitted. In other words, the emission has a spectrally narrow emission line, much like the discrete emission lines produced by hydrogen gas as the electrons relax from higher to lower energy levels. Due to the resemblance between the discrete emission lines from a QD and the atomic emission lines, these nanometer-sized QDs are sometimes referred to as artificial atoms.

An electron and a hole can be considered as a particle of mass $m$ moving freely in a rectangular box with impenetrable walls. The dimensions of the box are $2 a_{x}, 2 a_{y}, 2 a_{z}$. The solutions of the Schrödinger equation, including the energies, are as follows: 


$$
\begin{gathered}
\left(-\frac{\hbar^{2}}{2 m}\left(\frac{d^{2}}{d x^{2}}+\frac{d^{2}}{d y^{2}}+\frac{d^{2}}{d z^{2}}\right)+V(x, y, z)\right) \psi(x, y, z)=E \psi(x, y, z) \\
V(x, y, z)=\left\{\begin{array}{c}
0, \text { for } 0<x<2 a_{x}, 0<y<2 a_{y}, 0<z<2 a_{z} \\
\infty, \text { otherwise }
\end{array}\right.
\end{gathered}
$$

The wave function can be written in terms of its cartesian components ( $x$, $y$, and $z$ ):

$\psi(x, y, z)=\psi_{x}(x) \psi_{y}(y) \psi_{z}(z)$

The Schrödinger equation inside the box can thus be simplified to:

$-\frac{\hbar^{2}}{2 m}\left(\frac{1}{\psi_{x}(x)} \frac{d^{2} \psi_{x}(x)}{d x^{2}}+\frac{1}{\psi_{y}(y)} \frac{d^{2} \psi_{y}(y)}{d y^{2}}+\frac{1}{\psi_{z}(z)} \frac{d^{2} \psi_{z}(z)}{d z^{2}}\right)=E_{x}+E_{y}+E_{z}$

This yields the following equation in the $\mathrm{x}$ direction:

$-\frac{\hbar^{2}}{2 m} \frac{d^{2} \psi_{x}(x)}{d x^{2}}=E_{x} \psi_{x}(x)$

With the following solution:

$$
\begin{aligned}
& \psi_{x}(x)=A e^{i k_{x} x}+B e^{-i k_{x} x} \quad(\mathrm{~A} \text { and } \mathrm{B} \text { are complex constants }) \\
& k_{x}=\frac{\sqrt{2 m E_{x}}}{\hbar}
\end{aligned}
$$

The boundary conditions, $\psi_{x}(0)=\psi_{x}\left(2 a_{x}\right)=0$, yield this solution:

$$
\begin{aligned}
& 2 a_{x} k_{x}=n_{x} \pi \\
& k_{x}=\frac{n_{x} \pi}{2 a_{x}} \\
& E_{x}=\frac{k_{x}^{2} \hbar^{2}}{2 m}=\frac{n_{x}^{2} \pi^{2} \hbar^{2}}{8 m a_{x}^{2}} \\
& \psi_{x}(x)=C_{1} \sin \left(\frac{n_{x} \pi}{2 a_{x}} x\right), n_{x}=1,2,3, \ldots ; C_{1}=\text { constant }
\end{aligned}
$$

Similar solutions are obtained for $\psi_{y}(y)$ and $\psi_{z}(z)$, which lead to this final result: 


$$
\begin{aligned}
& \psi(x, y, z)=C \sin \left(\frac{n_{x} \pi}{2 a_{x}} x\right) \sin \left(\frac{n_{y} \pi}{2 a_{y}} y\right) \sin \left(\frac{n_{z} \pi}{2 a_{z}} z\right), C=C_{1} C_{2} C_{3} \\
& E=\frac{\pi^{2} \hbar^{2}}{8 m}\left(\frac{n_{x}^{2}}{a_{x}^{2}}+\frac{n_{y}^{2}}{a_{y}^{2}}+\frac{n_{z}^{2}}{a_{z}^{2}}\right)
\end{aligned}
$$

This solution can be modified to account for shape and composition of the QD and the surrounding barrier. Ultimately, by inputting the effective mass of the electron in the QD and its dimensions, the solution gives the probability to find the electron in different positions inside the $Q D$, given by the wave function in equation (3.17), and the energy of the electron state given by equation (3.18). By replacing the effective mass of the electron with the effective mass of the hole, the hole energy levels are also obtained. The final recombination energy of the electron-hole pair in the QD is the sum of the band gap energy, the electron energy level, and the hole energy level, minus the exciton binding energy. The overlap of the wavefunction of the electron and the hole gives a measure of the probability that the exciton will recombine. In other words, a large electron-hole wavefunction overlap leads to a short exciton lifetime (high probability of recombination), and vice versa.

Consider a QD with the possibility of occupying the ground state of the electron and the ground state of the hole. Each state can occupy two carriers (spin up and spin down). This allows for the following excitons to recombine: the single exciton $\left(X_{11}\right)$, the negatively charged exciton $\left(X_{21}\right)$, the positively charged exciton $\left(X_{12}\right)$, and the biexciton $\left(X_{22}\right)$. These excitons are depicted in Figure 3.3.

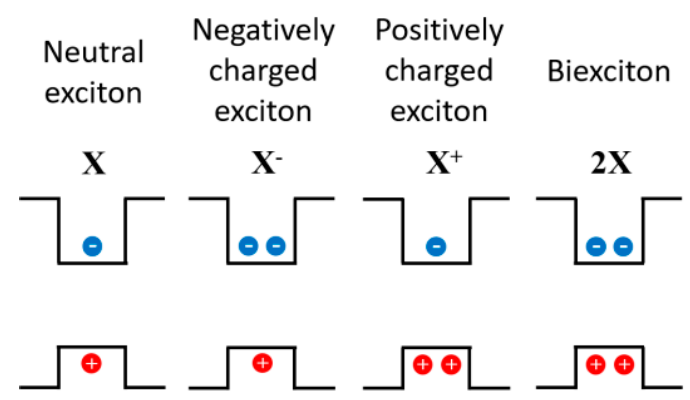

Figure 3.3: Excitons found in the ground state of a QD.

The probability of occupying these states $\left(X_{i j}\right)$ with $\mathrm{i}$ electrons and $\mathrm{j}$ holes is $p_{i j}(t)$. The electron capture time is called $t_{e}$, the hole capture time is 
called $t_{h}$, and the exciton (electron-hole pair) capture time is called $t_{e h}$. The capture times for an electron or hole when the QD is already populated by one or two holes or electrons, respectively, are assumed to be equal and denoted $\Delta t_{1}$ and $\Delta t_{2}$ for single excess and double excess charged. The capture time of an electron when the net charge of the system is already negative is increased by a factor of $c_{n}<1$ to $\frac{t_{e}}{c_{n}}$. Similarly, for holes, the capture time is increased to $\frac{t_{h}}{c_{p}}$. The increased capture time is a result of the Coulomb repulsion. The lifetime of the exciton state $X_{i j}$ is given the name $\tau_{i j}$. The possible states under consideration are shown in figure 3.4.

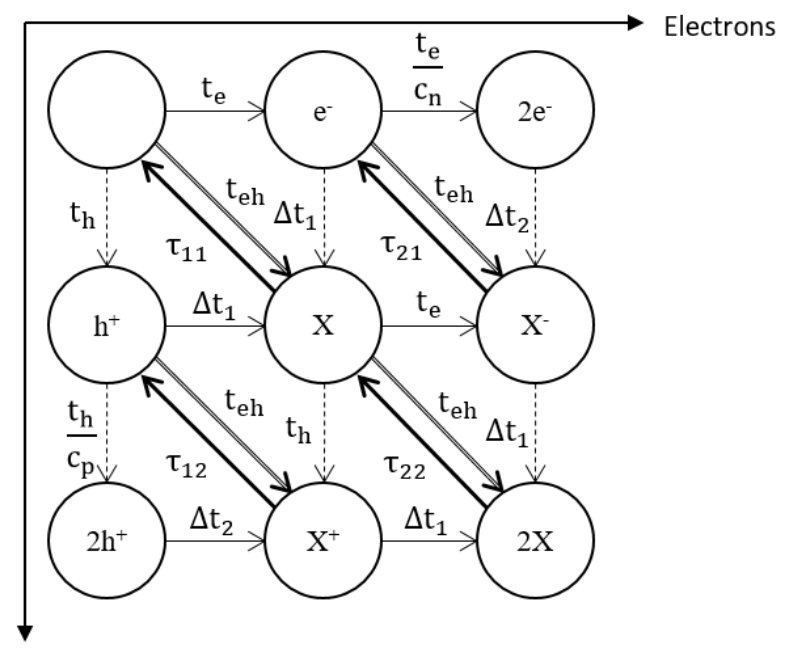

Holes

Figure 3.4: Possible occupation configurations of the first electron level and the first hole level in a QD, indicating the lifetimes and capture times between states.

The capture and recombination processes of this system can be explained by the following nine differential equations:

$$
\begin{aligned}
& \frac{\mathrm{dp}_{00}(\mathrm{t})}{\mathrm{dt}}=\mathrm{p}_{11}(\mathrm{t}) \frac{1}{\tau_{11}}-\mathrm{p}_{00}(\mathrm{t})\left(\frac{1}{\mathrm{t}_{\mathrm{e}}}+\frac{1}{\mathrm{t}_{\mathrm{h}}}+\frac{1}{\mathrm{t}_{\mathrm{eh}}}\right) \\
& \frac{\mathrm{dp}_{10}(\mathrm{t})}{\mathrm{dt}}=\mathrm{p}_{00}(\mathrm{t}) \frac{1}{\mathrm{t}_{\mathrm{e}}}+\mathrm{p}_{21}(\mathrm{t}) \frac{1}{\tau_{21}}-\mathrm{p}_{10}(\mathrm{t})\left(\frac{\mathrm{c}_{\mathrm{n}}}{\mathrm{t}_{\mathrm{e}}}+\frac{1}{\Delta \mathrm{t}_{1}}+\frac{1}{\mathrm{t}_{\mathrm{eh}}}\right)
\end{aligned}
$$




$$
\begin{aligned}
& \frac{\mathrm{dp}_{20}(\mathrm{t})}{\mathrm{dt}}=\mathrm{p}_{10}(\mathrm{t}) \frac{\mathrm{c}_{\mathrm{n}}}{\mathrm{t}_{\mathrm{e}}}-\mathrm{p}_{20}(\mathrm{t}) \frac{1}{\Delta \mathrm{t}_{2}} \\
& \frac{\mathrm{dp} \mathrm{p}_{01}(\mathrm{t})}{\mathrm{dt}}=\mathrm{p}_{00}(\mathrm{t}) \frac{1}{\mathrm{t}_{\mathrm{h}}}+\mathrm{p}_{12}(\mathrm{t}) \frac{1}{\tau_{12}}-\mathrm{p}_{01}(\mathrm{t})\left(\frac{1}{\Delta \mathrm{t}_{1}}+\frac{1}{\mathrm{t}_{\mathrm{eh}}}+\frac{c_{p}}{t_{h}}\right) \\
& \frac{\mathrm{dp} \mathrm{p}_{11}(\mathrm{t})}{\mathrm{dt}}=\mathrm{p}_{00}(\mathrm{t}) \frac{1}{\mathrm{t}_{\mathrm{eh}}}+\mathrm{p}_{10}(\mathrm{t}) \frac{1}{\Delta \mathrm{t}_{1}}+\mathrm{p}_{01}(\mathrm{t}) \frac{1}{\Delta \mathrm{t}_{1}}+\mathrm{p}_{22}(\mathrm{t}) \frac{1}{\tau_{22}}-\mathrm{p}_{11}(\mathrm{t})\left(\frac{1}{\tau_{11}}+\right. \\
& \left.\frac{1}{\mathrm{t}_{\mathrm{e}}}+\frac{1}{\mathrm{t}_{\mathrm{h}}}+\frac{1}{\mathrm{t}_{\mathrm{eh}}}\right) \\
& \frac{\mathrm{dp} \mathrm{p}_{21}(\mathrm{t})}{\mathrm{dt}}=\mathrm{p}_{10}(\mathrm{t}) \frac{1}{\mathrm{t}_{\mathrm{eh}}}+\mathrm{p}_{11}(\mathrm{t}) \frac{1}{\mathrm{t}_{\mathrm{e}}}+\mathrm{p}_{20}(\mathrm{t}) \frac{1}{\Delta \mathrm{t}_{2}}-\mathrm{p}_{21}(\mathrm{t})\left(\frac{1}{\tau_{21}}+\frac{1}{\Delta \mathrm{t}_{1}}\right) \\
& \frac{\mathrm{dp} \mathrm{p}_{02}(\mathrm{t})}{\mathrm{dt}}=\mathrm{p}_{01}(\mathrm{t}) \frac{\mathrm{c}_{p}}{\mathrm{t}_{h}}-\mathrm{p}_{02}(\mathrm{t}) \frac{1}{\Delta \mathrm{t}_{2}} \\
& \left.\frac{\mathrm{dt}}{\mathrm{dt}}=\mathrm{p}_{01}(\mathrm{t}) \frac{1}{\mathrm{dt}}=\mathrm{p}_{11}(\mathrm{t}) \frac{1}{\mathrm{t}_{\mathrm{eh}}}+\mathrm{p}_{11}(\mathrm{t}) \frac{1}{\mathrm{t}_{\mathrm{h}}}+\mathrm{p}_{02}(\mathrm{t}) \frac{1}{\Delta \mathrm{t}_{2}}-\mathrm{p}_{12}(\mathrm{t}) \frac{1}{\Delta \mathrm{t}}+\mathrm{p}_{12}(\mathrm{t}) \frac{1}{\Delta \mathrm{t}}-\mathrm{p}_{22}(\mathrm{t}) \frac{1}{\tau_{12}}+\frac{1}{\Delta \mathrm{t}_{1}}\right)
\end{aligned}
$$

The sum of the probabilities adds up to unity:

$\sum_{\mathrm{i}, \mathrm{j}=0}^{2} \mathrm{p}_{\mathrm{ij}}=1$

These rate equations improve the understanding of recombination and capture processes in QDs, and provide a theory for comparison with the experimental results. The rate equation and charge carrier dynamics have been thoroughly studied for InGaAs QDs, ${ }^{2}$ but InGaN QDs are less studied, which is addressed in Part 2 of the thesis. In the study of this thesis, a subset of the states in Figure 3.4 have been investigated, matching the experimentally observed neutral and negatively charged excitons. 


\section{III-Nitride Semiconductors}

III-nitride semiconductors have material properties that make them interesting for many applications. For electronic applications, high thermal conductivities, high temperature stability, and high breakdown fields are appealing, especially for high electron mobility transistors (HEMTs) of importance for high power and high frequency devices. For optoelectronic devices, which relates more closely to the work of this thesis, the wide range of band gap energies and the direct band gaps of the III-nitrides make them very appealing. In fact, combining GaN and InN (InGaN) allows for tuning the emission wavelength of the material from ultraviolet (UV) to infrared (IR), and covering the entire visible spectral region. With AIN, even deep UV emission is possible. Applications of IIInitride based light emitting devices span from water purification by UV light, to general illumination (white LEDs), displays, and communication related devices. Both classical and quantum optoelectronic devices are potential markets, in particular for QDs. ${ }^{3,4}$ With InGaN QDs, single photon emitters within a wide wavelength region is potentially possible, and their polarization tunability has been demonstrated, ${ }^{5}$ making this system very good for customizing the light emitting device to your needs.

GaN and InN have been the focus of this thesis. While some of their material parameters are well known, others are less well established. Table 4.1 summarizes parameters from the literature, as well as own 
calculations, which have been important for the investigations of this thesis.

\begin{tabular}{|c|c|c|}
\hline Material Property & GaN & InN \\
\hline$E_{g}$ & $3.510 \mathrm{eV}^{6}$ & $0.69 \mathrm{eV}^{7-11}$ \\
\hline$\epsilon_{r, \text { static }}^{\|}$ & $10.1^{12}$ & \\
\hline$\epsilon_{r, \text { static }}^{\perp}$ & $9.28^{12}$ & \\
\hline$\epsilon_{r, \text { static }}$ & 9.55 & $10.3^{13,14}$ \\
\hline$m_{e \|}$ & & $0.037 m_{0}{ }^{15}$ \\
\hline$m_{e \perp}$ & & $0.050 m_{0}{ }^{15}$ \\
\hline$m_{e}$ & $0.20 m_{0}{ }^{6,16}$ & $0.045 m_{0}$ \\
\hline$m_{h \|}$ & $1.76 m_{0}{ }^{17}($ A-band $)$ & $1.81 m_{0}{ }^{10}$ \\
\hline$m_{h \perp}$ & $0.35 m_{0}{ }^{17}($ A-band $)$ & $0.13 m_{0}{ }^{10}$ \\
\hline$m_{h}$ & $0.60 m_{0}$ & $0.31 m_{0}$ \\
\hline$m_{r}$ & $0.15 m_{0}$ & $0.040 m_{0}$ \\
\hline$E_{X, b}$ & $22 \mathrm{meV}$ & $5.1 \mathrm{meV}$ \\
\hline$a_{B}$ & $3.4 \mathrm{~nm}$ & $13.8 \mathrm{~nm}$ \\
\hline
\end{tabular}

Table: 4.1: Material parameters for GaN and InN: the band gap energy, parallel, perpendicular, and isotropically averaged values for the static dielectric constant and the effective electron and hole masses, the reduced mass, the exciton binding energy, and the free exciton Bohr radius.

For calculating the effective electron and hole masses based on the effective masses for the charge carriers moving parallel and perpendicular to the c-axis of the crystal, equation (4.1) has been used:

$$
m=\left(m_{\perp}^{2} \cdot m_{\|}\right)^{\frac{1}{3}}
$$

The reduced mass is given by equation (4.2):

$$
m_{r}=\left(\frac{1}{m_{e}}+\frac{1}{m_{h}}\right)^{-1}
$$

The free exciton Bohr radius, which is a measure of the size of the free exciton, is given by equation (4.3):

$$
a_{B}=\frac{4 \pi \epsilon_{0} \epsilon_{r} \hbar^{2}}{m_{r} e^{2}}
$$




$$
\begin{aligned}
& E_{H}=\frac{m_{0} e^{3}}{2\left(4 \pi \epsilon_{0} \hbar\right)^{2}}=13.6 \mathrm{eV} \\
& E_{X}^{n}=-\frac{m_{r} E_{H}}{m_{0} \epsilon_{r}^{2} n^{2}}
\end{aligned}
$$

So far, excitons in semiconductors have been considered to have welldefined binding energies. The exciton actually has excited states, with energies given by the hydrogen model in equation (4.5). The ground state, which is the commonly observed state, is obtained for $n=1$, which gives the effective mass based binding energy of the exciton (equation (4.6)); the energy needed to break the exciton apart into a free electron and a free hole.

$$
E_{X, b}=-E_{X}^{1}=\frac{m_{r} E_{H}}{m_{0} \epsilon_{r}^{2}}
$$




\section{Experimental Techniques}

\subsection{Metal Organic Chemical Vapor Deposition}

The pyramidal InGaN QD samples investigated within the work of this thesis consists of micrometer-sized GaN pyramids, with InGaN quantum wells (QWs), quantum wires (QWRs), and quantum dots (QDs). The samples have been grown using metal organic chemical vapor deposition (MOCVD) in a reaction chamber as illustrated in Fig. 5.1. This hot-wall type MOCVD reactor is characterized by a relatively uniform temperature across the sample during growth.

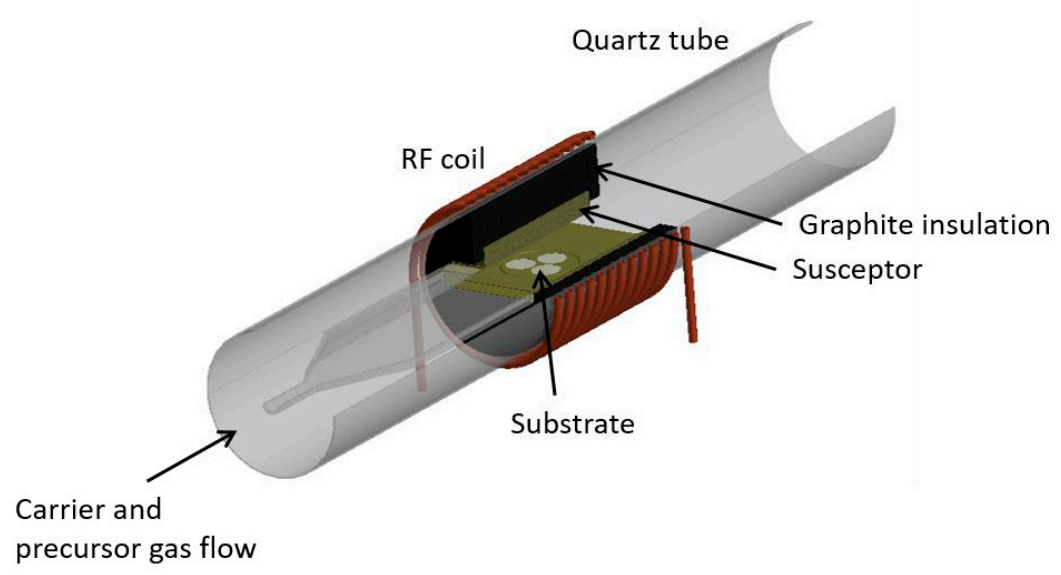

Figure 5.1: Hot-wall MOCVD reaction chamber. 
For the growths, $4 \mathrm{H} \mathrm{SiC} \mathrm{has} \mathrm{been} \mathrm{used} \mathrm{as} \mathrm{the} \mathrm{substrate.} \mathrm{The} \mathrm{first}$ deposition is a $100 \mathrm{~nm}$ AIN nucleation layer. This is followed by growing a $2 \mu \mathrm{m} \mathrm{GaN}$ layer and a SiN layer on top. The purpose of the SiN is to act as a template for patterning the sample. Circular holes down to diameters of $1.5 \mu \mathrm{m}$ are etched away from the SiN layer by photolithography, leaving $\mathrm{GaN}$ exposed in these openings. After the patterning, the sample is once again inserted into the MOCVD reaction chamber and heated to approximately $1060^{\circ} \mathrm{C}$ for the GaN growth. The GaN starts to grow inside the $\mathrm{SiN}$ holes on the exposed $\mathrm{GaN}$, and due to its wurtzite crystal structure, forms truncated hexagonal pyramids. If the growth is allowed to continue, the pyramids eventually form sharp apexes. This growth step takes about 17 minutes, depending on growth conditions, size of pyramids, and the amount of truncation aimed for. After completing the GaN pyramids growth, the temperature is reduced to $800{ }^{\circ} \mathrm{C}$ in order to grow a thin (several $\mathrm{nm}$ ) InGaN layer and a GaN cap (a few $\mathrm{nm}$ ), which takes approximately $50 \mathrm{~s}$ and $10 \mathrm{~min}$, respectively. The GaN cap grows very slowly due to the low temperature. Fig. 5.2 shows a schematic crosssection of a pyramid.

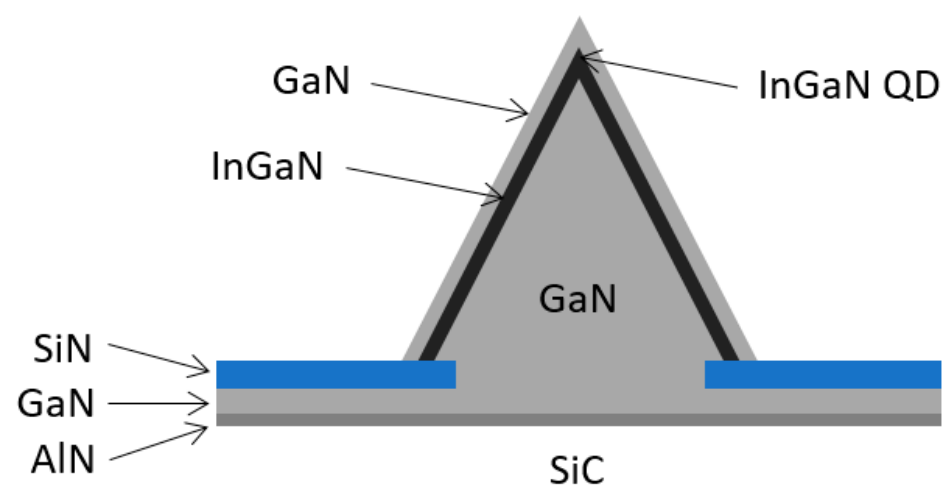

Figure 5.2: (a) Schematic cross-section of a pyramid.

This structure contains QWs on the facets of the pyramids, QWRs along the edges of the facets, and QDs on the apexes of the pyramids. The InGaN layer contains just a few percent of In. 


\subsection{Imaging Microscopy}

There are many microscopy techniques for imaging samples. The most common, easiest, and least destructive technique is optical microscopy. This technique utilizes light (photons) to image the sample. The diffraction limit of the light waves sets a limit of half of the wavelength of the light on the spatial resolution of the images recorded assuming perfect focus and no aberrations in the optics. Using red light with a wavelength of 700 $\mathrm{nm}$ yields accordingly a best possible resolution of $350 \mathrm{~nm}$, while violet light with a wavelength of $400 \mathrm{~nm}$ yields a theoretically best resolution of $200 \mathrm{~nm}$. Chromatic aberration, is one imperfection of imaging systems that limits the resolution, which manifests as a blurred image due to different wavelengths of light with different wavelengths, due to the wavelength dependence of the index of refraction of the lenses used in the optical microscope. Another issue is spherical aberration, which is related to imperfectness in the lenses used, leading to a shift in focus of the light transmitted through the lens, dependent on the transmission path through the lens. In addition to limiting and correcting for these aberrations, there is an inherent limit in the resolution of the microscope due to the wavelength of the imaging particles used (photons), which is overcome by changing imaging particles.

By using electrons to image samples, the diffraction limit, and therefore the resolution of the microscope, is significantly improved, with resolutions in the order of nanometers for scanning electron microscopes (SEM), and sub-Ångström resolutions of transmission electron microscopes (TEM), allowing single atoms to be imaged. This high resolution is due to the very short wavelength of the electrons used, as determined by the wave-particle duality:

$$
\lambda=\frac{h}{p}
$$

Waves can be considered as particles, and particles can be considered as waves, and their relationship is described by equation (5.1), where $\lambda$ is the wavelength, $h$ is Planck's constant, and $p$ is the momentum of the particle. A photon is a single quantum of light (a light particle), and has a certain momentum, and it can simultaneously be described as a light wave with a certain wavelength. The same is true for electrons, which are 
massive particles with momenta determined by the product of their mass and speed. Equation 5.1 tells us that the electrons also have a de Broglie wavelength, which decreases with increasing speed of the electrons. Hence, high resolution electron microscopy images are recorded by accelerating the electrons to high speeds. Increasing the energy of the electrons in the electron beam is done by increasing the acceleration voltage. However, for studying the sample close to the surface, a low acceleration voltage is beneficial, as this reduces the penetration depth of the electron beam. The SEM images within the work of this thesis have been recorded with electrons accelerated to kinetic energies of $5-10 \mathrm{keV}$.

When the accelerated electrons, called primary electrons, reach the sample, some are scattered at the surface, but most penetrate into the sample. Even inside the sample, some electrons are scattered back towards the detector. Back-scattered primary electrons can be used to create an image of the sample. The primary electrons scatter both elastically (scatter by nuclei) and inelastically (loose energy and slow down) in the sample under study. By inelastic scattering, electrons in the outer shells of atoms can be excited out of the atom. These electrons are called secondary electrons and can be used to give a contrast image of the sample surface in a similar manner as the primary electrons. Figure 5.3 is an SEM image, showing relatively large pyramids.

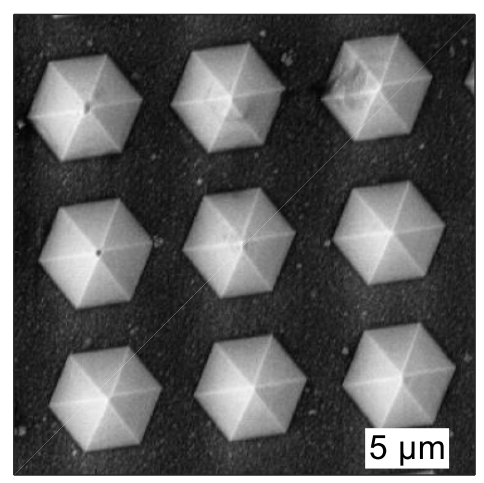

Figure 5.3: SEM image of relatively large GaN pyramids.

Inelastic scattering of the primary electrons can also lead to excitation of electrons in inner shells close to the nucleus of atoms, leading to the emission of Auger electrons and characteristic X-rays. Continuous 
inelastic scattering of the primary electrons leads to Bremsstrahlung (continuous $\mathrm{X}$-rays). When the primary electrons interact with the sample, the electrons in the sample can also be excited to higher energy states and emit luminescence (cathodoluminescence) as they relax to lower energy states.

\subsection{Photoluminescence Spectroscopy}

For light to be emitted from the semiconductor (luminescence), it first needs to be excited, so that the charge carriers subsequently can relax and emit photons. Electroluminescence (EL) Is luminescence created by electrical ejection of charge carriers into the sample, such as in light emitting diodes (LEDs). Cathodoluminescence $(C L)$ is luminescence produced by exciting the sample with a cathode ray (electron beam). Photoluminescence (PL) is luminescence emitted as a result of photoexcitation, generally through the use of a laser.

The PL process is described in Figure 5.4. First, a laser with an energy at least as high as the band gap energy of the material investigated excites electrons from the valence band up into the conduction band (one laser photon excites one electron). Then the electrons relaxes to the bottom of the conduction band by emitting phonons. After a characteristic lifetime, the electrons recombine with holes in the valence band and sends out photons (PL). For every recombination of an electron with a hole, one photon is emitted.
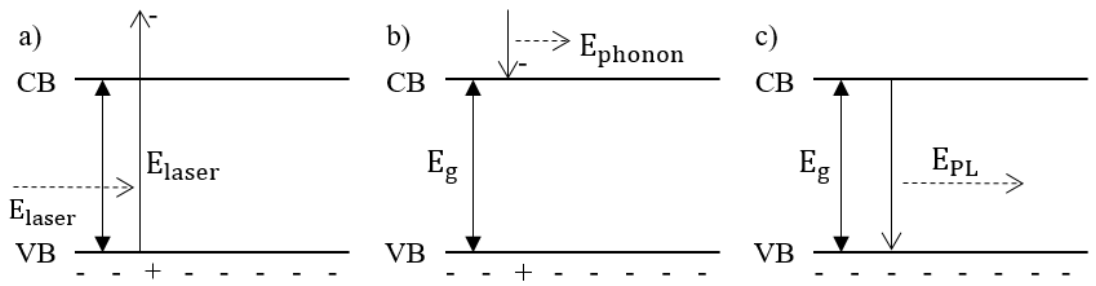

Figure 5.4: (a) Exciting an electron from the valence band to the conduction band by absorbing a laser photon. (b) Relaxation of an excited electron to the bottom of the conduction band, by releasing one or more phonons (lattice vibrations). (c) Relaxation of an electron by recombining with a hole in the valence band, resulting in the emission of a photon (photoluminescence). 
The energy of the emitted photon has an energy corresponding to the difference in the energy of the electron and the hole before the recombination process. Thus, PL spectroscopy gives information about the relative positions of energy levels, and can also provide information for determining the binding energies of bound states, such as the free exciton binding energy or the donor binding energy, along with many other energy levels and optical properties.

After exciting the sample with a laser, the PL signal is collected by a lens and guided to a spectrometer for recording a spectrum of the emitted light. The PL signal is focused on the entrance slit of the spectrometer and the illuminated slit is imaged on the charge coupled device (CCD) on the other side of the spectrometer. To obtain spectral information of the light, it is diffracted by a grating inside the spectrometer prior to being focused on the CCD, as described in Figure 5.5.

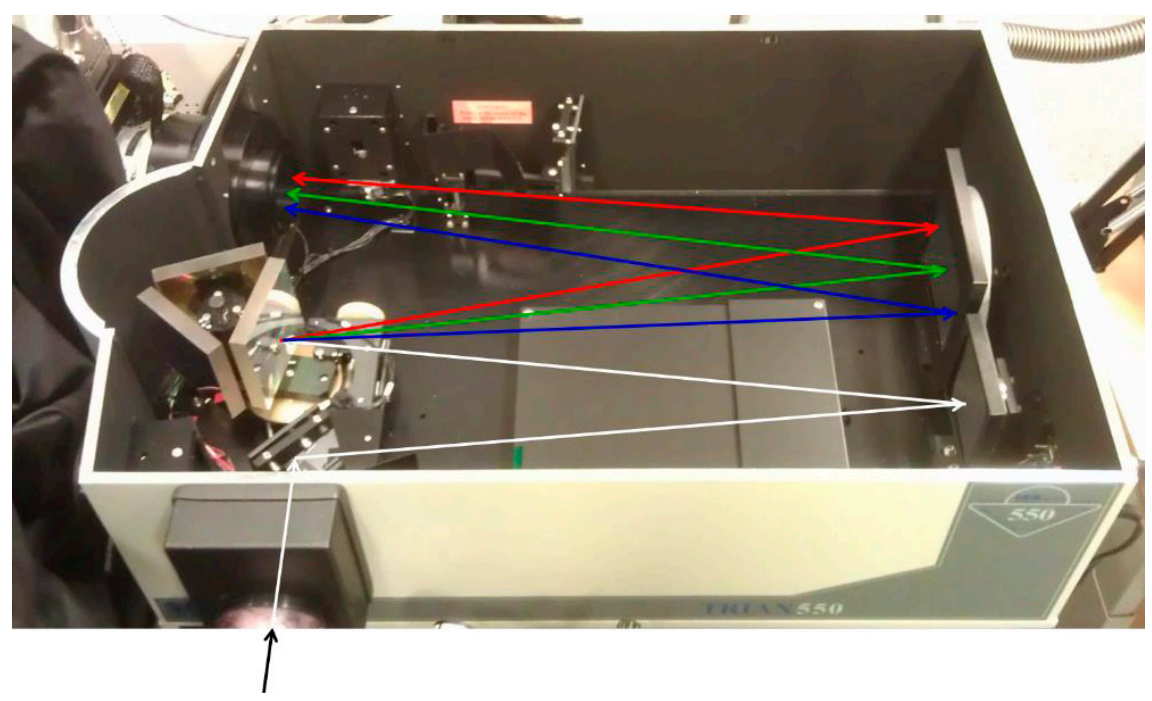

Figure 5.5: Picture of opened spectrometer, with light path indicated. The entrance slit is in the bottom left hand corner, and the liquid nitrogen cooled CCD is mounted outside the spectrometer in the top left hand corner.

The temperature of the semiconductor sample being studied is an important parameter with respect to the luminescence. At room temperature, the phonon energy is relatively high, leading to significant temperature related effects, such as band gap narrowing with increasing temperatures. At considerably high phonon energies, spectral features 
also undergo thermal broadening due to the spread of charge carrier population among different energy levels. As charge carriers are thermally excited, more of them may reach defect states, both within the semiconductor crystal and at the surface. This can result in a lower internal quantum efficiency for the radiative emission. In order to overcome these thermal effects and measure luminescence at cryotemperatures (close to $0 \mathrm{~K}$ ), liquid helium can be utilized. The PL spectroscopy conducted within the work of this thesis has generally been conducted at $5 \mathrm{~K}$.

With similar reasoning, the CCD has to be cooled down, in order to suppress thermally excited charge carriers that result in high noise levels, and also for improving the sensitivity of the detector. The steady state micro-PL spectrometer has a liquid nitrogen cooled CCD operating at a temperature of $150 \mathrm{~K}$, whereas the time resolved micro-PL setup has a Peltier (thermoelectrically) cooled CCD.

At $5 \mathrm{~K}$, the PL spectrum is blue-shifted due to band gap enlargement and thermal effects such as spectral broadening and lower radiative efficiency can be significantly reduced. There is another fundamental importance of conducting measurements at low temperatures as compared to high temperatures; different states will be observed. Consider heterostructures such as QWs or QDs with barrier heights that are comparable to or lower than the thermal energy at room temperature. Charge carriers will not stay inside these quantum wells or quantum dots at room temperature, due to the thermal excitation of the charge carriers. At $5 \mathrm{~K}$, however, the electrons and holes, will relax to the lowest states, which means that the QWs and QDs can be populated. This in turn allows for detection of photon emission from these quantum structures as the electrons and holes recombine. Cooling with liquid helium is thus crucial for characterization of certain states of some samples.

The PL spectra are recorded as counts vs. wavelength. However, when discussing energy states in the semiconductor, plotting the spectrum as a function of energy is more useful. The energies of the emitted photons are calculated using equation (5.2).

$$
E=h v=\frac{h c_{0}}{\lambda_{0}}=\frac{h c_{0}}{n_{\text {air }} \lambda_{\text {air }}}
$$


The constant $h$ is Planck's constant, $c_{0}$ is the speed of light in vacuum, $n_{\text {air }}$ is the index of refraction of air under certain conditions and for a specific wavelength, and $\lambda_{\text {air }}$ is the wavelength of the photons measured by the spectrometer (assuming measurements are being done in air). Setting the index of refraction of air to 1.0003 (for blue light at room temperature and standard atmospheric pressure and humidity), the relation between energy in $\mathrm{eV}$ and wavelength in $\mathrm{nm}$ equates to:

$$
E[\mathrm{eV}]=\frac{1239.49}{\lambda_{\text {air }}[\mathrm{nm}]}
$$

\subsection{Steady State Micro-Photoluminescence Spectroscopy}

For the study of InN films, conventional PL spectroscopy was used, while micro-photoluminescence ( $\mu \mathrm{PL}$ ) spectroscopy was utilized for the investigations of individual QDs. There are two major differences between conventional macro-PL and $\mu \mathrm{PL}$ spectroscopy. Firstly, a microscope objective (in our case a reflecting type of microscope objective) is used to focus the excitation laser to a spot size of approximately $2 \mu \mathrm{m}$, allowing small areas to be studied, compared to the much larger excitation area of conventional PL spectroscopy, where a lens is used to focus the laser. Secondly, the sample is illuminated by a lamp that creates an image of the sample that is detected by a video camera, which allows accurate information about the position of the laser on the sample to be obtained. A schematic diagram of the time resolved $\mu \mathrm{PL}$ spectroscopy setup is illustrated in Figure 5.7, which apart from the addition of a streak unit and pulsed excitation, is similar to the steady state $\mu \mathrm{PL}$ spectroscopy setup.

The small excitation area together with micrometer-sized separation of the pyramids housing the InGaN QDs, allows for individual QDs to be studied. For the study of the InGaN QDs, generally a $266 \mathrm{~nm}$ continuous wave $(\mathrm{CW})$ laser has been used to excite the samples for the steady state $\mu \mathrm{PL}$ investigations. Figure 5.6 is an example of a PL spectrum, indicating the origin of the luminescence from a GaN pyramid with InGaN QWs and an InGaN QD. 


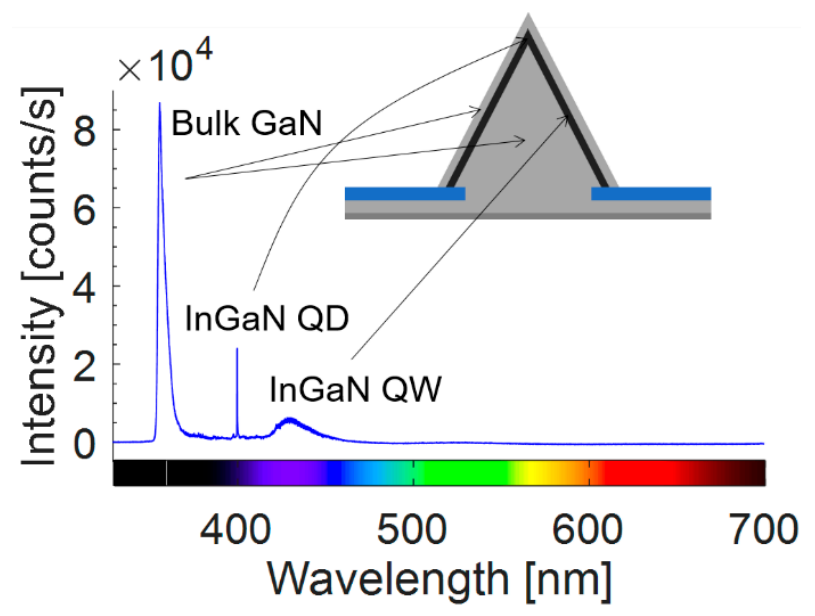

Figure 5.6: PL spectrum of pyramid, indicating bulk GaN luminescence, InGaN QW luminescence, and InGaN QD luminescence.

From photoluminescence studies at $4 \mathrm{~K}$, it has been seen that the QDs emit around $380-420 \mathrm{~nm}$, very with distinct and sharp spectral peaks for the case of one or just a few QDs on a single apex. The luminescence from the QWs, however, produces luminescence with a large variety of wavelengths, resulting in a spectral band that can be broader than $10 \mathrm{~nm}$. This broad emission is due to a variety of thickness, and possibly composition, of the QWs along the facets. At room temperature, the QD emission is lost, due to a shallow confinement with the present sample design.

\subsection{Time Resolved Micro-Photoluminescence Spectroscopy}

For insight into the dynamics of the QDs, and measuring the lifetimes of their excitons, time resolved $\mu \mathrm{PL}(\mathrm{TR} \mu \mathrm{PL})$ spectroscopy has been a useful tool. This technique is similar to the steady state $\mu \mathrm{PL}$ spectroscopy technique described above, with two important differences. Firstly, the laser used to excite the sample is pulsed. Secondly, a streak camera is used in order to record information about the PL signal over time ( $2 \mathrm{~ns}$ or less). Figure 5.7 shows a schematic of the TR $\mu \mathrm{PL}$ spectroscopy setup used, which if removing the streak unit becomes similar to the steady state $\mu \mathrm{PL}$ spectroscopy setup used. 


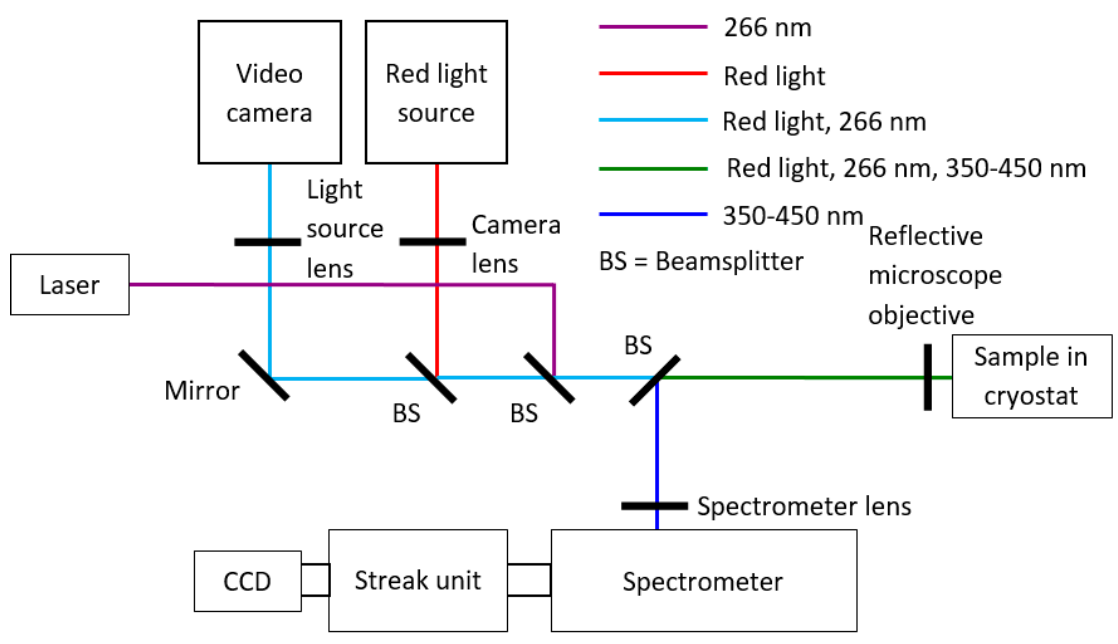

Figure 5.7: The TR $\mu \mathrm{PL}$ spectroscopy setup. The colored lines indicate the important wavelengths that traverse the optical path.

The operation of the streak camera is explained in Figure 5.8. Spectrally dispersed photons from the spectrometer enter the streak camera as a horizontal plane of light. In the streak unit, photons are first converted to electrons by a photocathode. These electrons are accelerated across the streak tube and hit a phosphor on the other side, which converts the electrons back into photons, which are detected by a Peltier cooled CCD. Inside the streak tube, perpendicular to the direction of travel of the electrons, electrodes form an oscillating electric field, with a frequency that is synchronized to the pulse frequency $(75 \mathrm{MHz})$ of the laser used to excite the sample. When a photon hits the CCD, its horizontal position determines the wavelength (energy) of the photon, and its vertical position on the CCD determines the point in time in relation to the excitation (laser) pulse. Only the close to linear part of the electron wave is used to form the image on the CCD, as seen in Figure 5.8 (b and c). An example of a resulting image on the CCD can look like that of Figure 5.8 (d), which is the luminescence of neutral and negatively charged excitons in an InGaN pyramidal QD. 


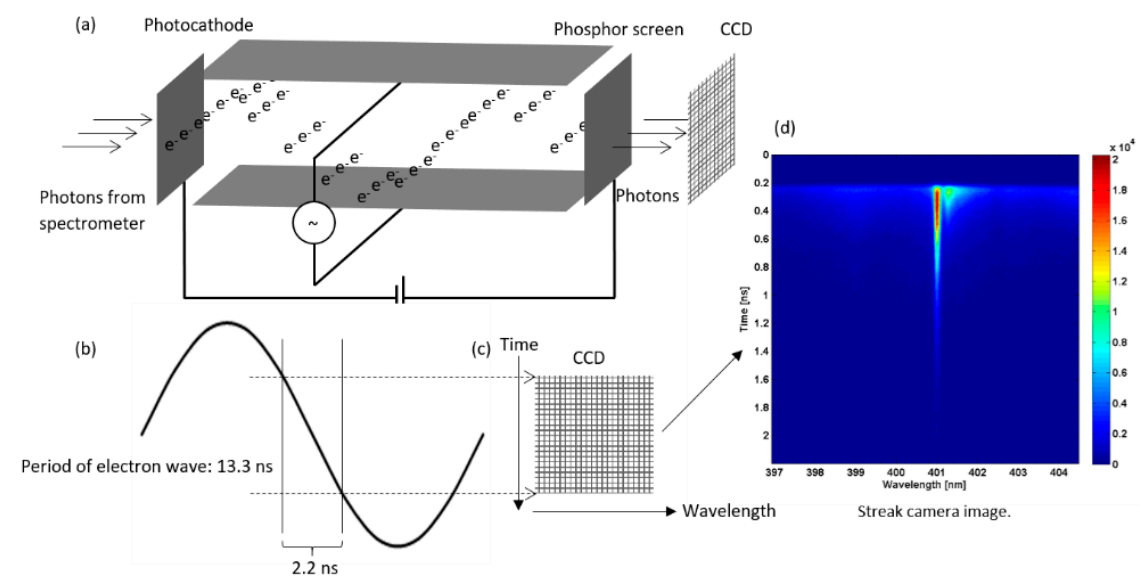

Figure 5.8: (a) Schematic diagram of the streak camera. (b) One period of the electron wave in the streak tube, hitting the CCD (c), and forming the resulting image in (d).

\subsection{Cathodoluminescence Spectroscopy}

Cathodoluminescence is light emitted by a sample upon excitation by an electron beam. An SEM is used as a source of the electron beam, with electrons having a few $\mathrm{keV}$ and up to several tens of keV of energy. By increasing the acceleration voltage, the penetration depth of the electrons is increased, and the cathodoluminescence originates from a larger volume inside the sample. The emitted photons may be absorbed back into the sample on the way out, leading to a volume of generated cathodoluminescence that reaches the detector that is smaller than the excitation volume. A theoretical study has been made that shows the generated cathodoluminescence that escapes the sample as a function of depth into the sample. ${ }^{18}$ According to this study, exciting the sample with electrons that have an energy of $5 \mathrm{keV}$ results in detectable cathodoluminescence from the sample within approximately the top 200 $\mathrm{nm}$, and increasing the acceleration voltage to $20 \mathrm{kV}$ results in detectable cathodoluminescence that originates from deeper than $1 \mu \mathrm{m}$ into the sample.

Cathodoluminescence has similarities with photoluminescence, where electrons and holes are excited by photons (typically a laser) and relax to the ground states by emitting photons. For cathodoluminescence 
spectroscopy, the high energy primary electrons excite the electrons in the sample to many more states as compared to laser excitation. Consequently, cathodoluminescence gives information about more energy states. The wavelengths of the emitted photons correspond to the difference in energy between an electron and a hole before they recombine.

The cathodoluminescence can be collected in different ways, each giving different information about the sample under investigation. By scanning the electron beam across the sample, a cathodoluminescence image can be obtained. For each position of the electron beam, one pixel in the cathodoluminescence image is created. To create a panchromatic image, all wavelengths of the emitted light is detected by a photomultiplier tube (PMT), resulting in an image that informs about the intensity of the light emitted by the sample across the area studied. Alternatively, the light can be diffracted by a grating in a monochromator and only a given wavelength region is monitored by the PMT. This will inform about which regions of the sample that give rise to different parts of the cathodoluminescence spectrum. The spatial resolution of the cathodoluminescence images depends on the sample, the measurement conditions, and the alignment, but is typically better than $100 \mathrm{~nm}$. To obtain a cathodoluminescence spectrum, the light is diffracted by the grating as mentioned above, but instead of monitored by the PMT, it is detected by a CCD, which has a matrix of pixels that can detect the light. Along one dimension, the pixels are binned together, resulting in one data point in the resulting spectrum of light intensity as a function of wavelength. A cathodoluminescence spectrum can be acquired for either a fixed position of the sample or as an average spectrum over a larger region by letting the electron beam be scanned across the sample. By combining the above mentioned techniques of recording the cathodoluminescence, detailed information about both electron energy states and the two dimensional spatial origin of these states can be obtained. 


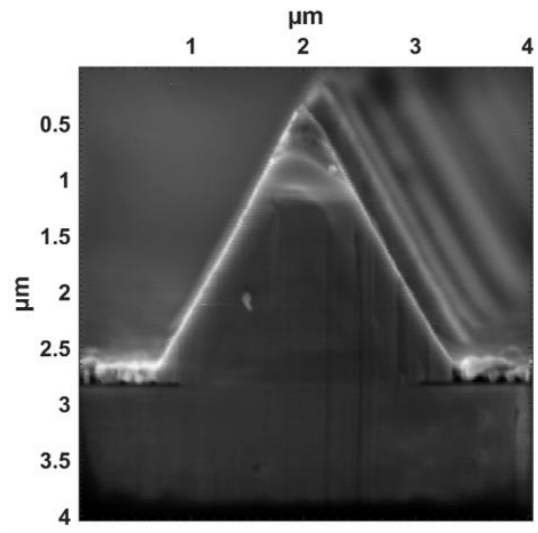

SEM

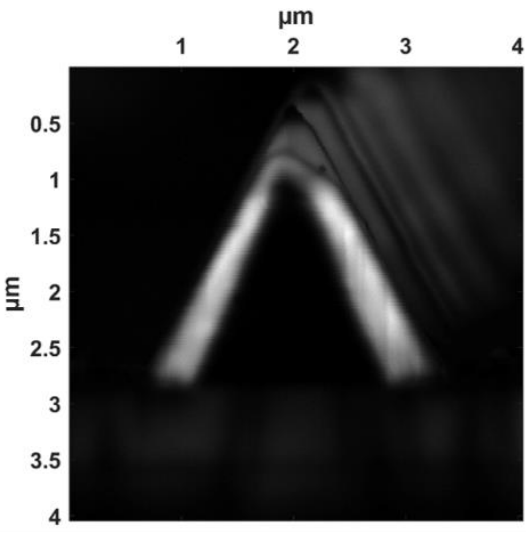

Panchromatic CL

Figure 5.9: SEM image and panchromatic $C L$ image of the cross-section of a GaN pyramid recorded at $8 \mathrm{~K}$.

From CL spectroscopy, it has been possible to detect inhomogeneous light emitting properties from the core of pyramids. Figure 5.9 shows an SEM image and a panchromatic image of a cross-section of a pyramid recorded at $8 \mathrm{~K}$. It is evident that the part of the pyramid that has overgrown the SiN mask emits strong luminescence, whereas the core of the pyramid is dark. This can be explained by threading dislocations, which has also been observed for other pyramids. ${ }^{19}$ 


\subsection{Enhancing Light Emission Quality of Quantum Dots}

Many times, the PL signal from the QDs overlaps with other emission from the pyramids, making investigations of these QDs difficult. It has been seen in $\mathrm{CL}$ images that emission originates from the sidewalls of the pyramids, and in some cases the dominating emission comes from the base of the pyramids. In order to minimize the background emission, samples can be metallized by aluminum, while keeping the apex exposed (uncoated). This procedure significantly reduces the background emission from the pyramids, as seen in Figure 5.10.

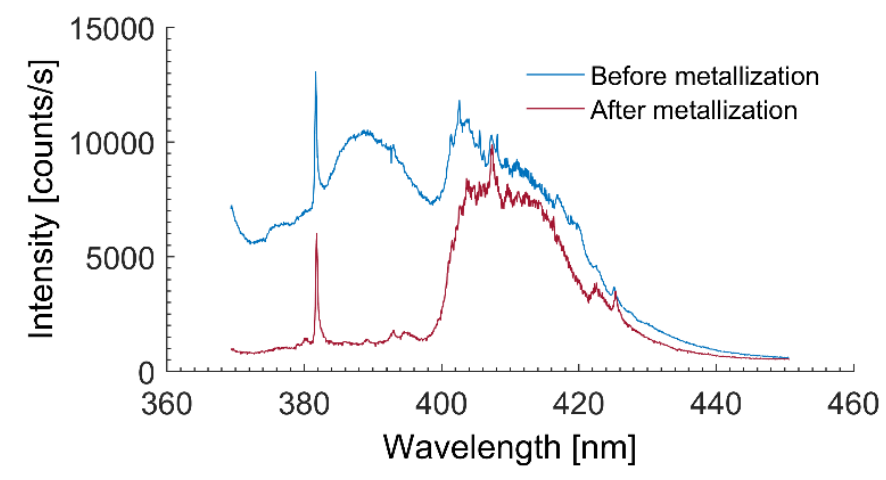

Figure 5.10: $\mu \mathrm{PL}$ spectra before and after metallizing the pyramids with aluminum while keeping the apex exposed. 


\section{References}

${ }^{1}$ K. Seeger, Semiconductor Physics : An Introduction, 6th editio (SpringerVerlag, Berlin, Heidelberg, 1997).

${ }^{2}$ M.H. Baier, A. Malko, E. Pelucchi, D.Y. Oberli, and E. Kapon, Phys. Rev. B 73, 205321 (2006).

${ }^{3}$ D. Bimberg, M. Kuntz, and M. Laemmlin, Microelectronics J. 36, 175 (2005).

${ }^{4}$ C. Kurtsiefer, P. Zarda, M. Halder, H. Weinfurter, P.M. Gorman, P.R. Tapster, and J.G. Rarity, Nature 419, 450 (2002).

${ }^{5}$ A. Lundskog, C.-W. Hsu, K. Fredrik Karlsson, S. Amloy, D. Nilsson, U. Forsberg, P. Olof Holtz, and E. Janzén, Light Sci. Appl. 3, e139 (2014).

${ }^{6}$ I. Vurgaftman and J.R. Meyer, J. Appl. Phys. 94, 3675 (2003).

7 J. Wu, W. Walukiewicz, W. Shan, K.M. Yu, J.W. Ager, E.E. Haller, H. Lu, and W.J. Schaff, Phys. Rev. B 66, 201403 (2002).

${ }^{8}$ J. Wu, W. Walukiewicz, W. Shan, K.M. Yu, J.W. Ager, S.X. Li, E.E. Haller, H. Lu, and W.J. Schaff, J. Appl. Phys. 94, 4457 (2003).

9 B. Arnaudov, T. Paskova, P.P. Paskov, B. Magnusson, E. Valcheva, B. Monemar, H. Lu, W.J. Schaff, H. Amano, and I. Akasaki, Phys. Rev. B 69, 115216 (2004).

${ }^{10}$ P. Rinke, M. Winkelnkemper, A. Qteish, D. Bimberg, J. Neugebauer, and M. Scheffler, Phys. Rev. B - Condens. Matter Mater. Phys. 77, 75202 (2008).

${ }^{11}$ M. Millot, N. Ubrig, J.-M. Poumirol, I. Gherasoiu, W. Walukiewicz, S. George, O. Portugall, J. Léotin, M. Goiran, and J.-M. Broto, Phys. Rev. B 83, 125204 (2011).

${ }^{12}$ T. Azuhata, T. Sota, K. Suzuki, and S. Nakamura, J. Phys. Condens. Matter 7, 129 (1995).

${ }^{13}$ B.R. Nag, Phys. Status Solidi 237, R1 (2003).

${ }^{14}$ T. Inushima, K. Fukui, H. Lu, and W.J. Schaff, Appl. Phys. Lett. 92, 171905 (2008).

${ }^{15}$ T. Hofmann, V. Darakchieva, B. Monemar, H. Lu, W.J. Schaff, and M. 
Schubert, J. Electron. Mater. 37, 611 (2008).

${ }^{16}$ M. Drechsler, D.M. Hofmann, B.K. Meyer, T. Detchprohm, H. Amano, and I. Akasaki, Jpn. J. Appl. Phys. 34, L1177 (1995).

${ }^{17}$ A. V. Rodina, M. Dietrich, A. Göldner, L. Eckey, A. Hoffmann, A.L. Efros, M. Rosen, and B.K. Meyer, Phys. Rev. B 64, 115204 (2001).

${ }^{18}$ K. Fleischer, M. Toth, M.R. Phillips, J. Zou, G. Li, and S.J. Chua, Appl. Phys. Lett. 74, 1114 (1999).

19 T. Riemann, J. Christen, B. Beaumont, J.P. Faurie, and P. Gibart, Superlattices Microstruct. 36, 833 (2004). 


\section{List of Publications}

\subsection{Papers Included in the Thesis}

I. InGaN quantum dot formation mechanism on hexagonal GaN/InGaN/GaN pyramids

A. Lundskog, J. Palisaitis, C. W. Hsu, M. Eriksson, K. F. Karlsson, L. Hultman, P. O. Å. Persson, U. Forsberg, P. O. Holtz, and E. Janzén

Nanotechnology 23, 305708 (2012)

I was active in the planning, and performed the polarization resolved photoluminescence measurements and was active in the analysis and interpretation of the results and revision of the manuscript.

II. Dynamic characteristics of the exciton and the biexciton in a single InGaN quantum dot

S. Amloy, E. S. Moskalenko, M. Eriksson, K. F. Karlsson, Y. T. Chen, K. H. Chen, H. C. Hsu, C. L. Hsiao, L. C. Chen, and P. O. Holtz

Applied Physics Letters 101, 061910 (2012)

I was active in the planning, and performed the time resolved micro-photoluminescence measurements and was active in the analysis and interpretation of the results, and wrote part of the paper.

III. The charged exciton in an InGaN quantum dot on a GaN pyramid

C. W. Hsu, E. S. Moskalenko, M. O. Eriksson, A. Lundskog, K. F. Karlsson, U. Forsberg, E. Janzén, and P. O. Holtz Applied Physics Letters 103, 013109 (2013)

I was active in the planning, and performed the time resolved micro-photoluminescence measurements, and was active in the analysis and interpretation of the results, and wrote part of the paper. 
IV. The Appearance of Remotely Charged Excitons in a Pyramidal InGaN Quantum Dot

M. O. Eriksson, C. W. Hsu, K. F. Karlsson, J. P. Bergman, and P. O. Holtz

In manuscript

I was active in the planning, and performed most of the measurements, all the analysis, and most of the interpretation of the results, and I wrote the paper.

V. Small InGaN Pyramidal Quantum Dots to Minimize the Internal Field Effects

M. O. Eriksson, C. W. Hsu, K. F. Karlsson, J. P. Bergman, E. Janzén, and P. O. Holtz

In manuscript

I was active in the planning, and performed all the measurements and most of the analysis and interpretation of the results, and I wrote the paper.

VI. Charge Carrier Dynamics of InGaN Pyramidal Quantum Dots M. O. Eriksson, C. W. Hsu, K. F. Karlsson, J. P. Bergman, and P. O. Holtz In manuscript

I was active in the planning and performed most of the measurements, all the analysis, and most of the interpretation of the results, and I wrote the paper.

VII. Effect of Mg Doping on the Optical Properties of InN Films M. O. Eriksson, S. Khromov, X. Wang, A. Yoshikawa, P. O. Holtz, B. Monemar, and V. Darakchieva In manuscript

I was active in the planning and performed most of the photoluminescence measurements and the majority of the analysis and interpretation of the results, and I wrote most of the paper. 


\subsection{Papers Not Included in the Thesis}

I. Comparative micro-photoluminescence investigation of $\mathrm{ZnO}$ hexagonal nanopillars and the seeding layer grown on $4 \mathrm{H}-\mathrm{SiC}$

J. W. Sun, V. Khranovskyy, M. Mexis, M. Eriksson, M. Syväjärvi, I. Tsiaoussis, G. R. Yazdi, H. Peyre, S. Juillaguet, J. Camassel, P. O. Holtz, P. Bergman, L. Hultman, and R. Yakimova

Journal of Luminescence 132, 122 (2012)

II. Improvements in Optical Properties of (0001) ZnO Layers Grown on (0001) Sapphire Substrates by Halide Vapor Phase Epitaxy Using Thick Buffer Layers

R. Masuda, C. W. Hsu, M. Eriksson, Y. Kumagai, A. Koukitu, and P. O. Holtz

Japanese Journal of Applied Physics 51, 031103 (2012)

III. Improvement of Crystalline and Photoluminescence of Atomic Layer Deposited m-Plane ZnO Epitaxial Films by Annealing Treatment

S. Yang, B. H. Lin, C. C. Kuo, H. C. Hsu, W. R. Liu, M. O. Eriksson, P. O. Holtz, C. S. Chang, C. H. Hsu, and W. F. Hsieh

Crystal Growth \& Design 12, 4745 (2012)

IV. Hydrothermal Growth of Vertically Aligned ZnO Nanorods Using a Biocomposite Seed Layer of ZnO Nanoparticles

Z. H. Ibupoto, K. Khun, M. Eriksson, M. AlSalhi, M. Atif, A. Ansari, and $\mathrm{M}$. Willander

Materials 6, 3584 (2013)

V. Surface related and intrinsic exciton recombination dynamics in $\mathrm{ZnO}$ nanoparticles synthesized by a sol-gel method

H. C. Hsu, H. Y. Huang, M. O. Eriksson, T. F. Dai, and P. O. Holtz Applied Physics Letters 102, 013109 (2013) 
VI. Photoluminescence study of basal plane stacking faults in ZnO nanowires

V. Khranovskyy, M. O. Eriksson, G. Z. Radnoczi, A. Khalid, H. Zhang, P. O. Holtz, L. Hultman, and R. Yakimova Physica B 439, 50 (2014)

VII. Recombination dynamics of a localized exciton bound at basal stacking faults within the $\mathrm{m}$-plane $\mathrm{ZnO}$ film

S. Yang, H. C. Hsu, W. R. Liu, B. H. Lin, C. C. Kuo, C. H. Hsu, M. O. Eriksson, P. O. Holtz, and W. F. Hsieh Applied Physics Letters 105, 011106 (2014)

VIII. Effect of $\mathrm{Ag}$ doping on the microstructure and photoluminescence of $\mathrm{ZnO}$ nanostructures

V. Khranovskyy, I. Tsiaoussis M. Eriksson, and R. Yakimova

Physica Status Solidi (a) Applications and Materials Science 211, 2109 (2014)

IX. Excitons and biexcitons in InGaN quantum dot like localization centers

S. Amloy, K. F. Karlsson, M. O. Eriksson, J. Palisaitis, P. O. Å. Persson, Y. T. Chen, K. H. Chen, H. C. Hsu, C. L. Hsiao, L. C. Chen, and P. O. Holtz Nanotechnology 25, 495702 (2014)

$X$. Low temperature near band edge recombination dynamics in $\mathrm{ZnO}$ nanorods

Z. N. Urgessa, J. R. Botha, M. O. Eriksson, C. M. Mbulanga, S. R. Dobson, S. R. T. Djiokap, K. F. Karlsson, V. Khranovskyy, R. Yakimova, and P. O. Holtz Journal of Applied Physics 116, 123506 (2014) 
XI. Continuous sensing of hydrogen peroxide and glucose via quenching of the UV and visible luminescence of $\mathrm{ZnO}$ nanoparticles

D. Sodzel, V. Khranovskyy, V. Beni, A. P. F. Turner, R. Viter, M.

O. Eriksson, P. O. Holtz, J. M. Janot, M. Bechelany, S. Balme, V. Smyntyna, E. Kolesneva, L. Dubovskaya, I. Volotovski, A. Ubelis, and R. Yakimova

Microchim Acta 182, 1819 (2015)

XII. A detailed optical investigation of ZnO@ZnS core-shell nanoparticles and their photocatalytic activity at different pH values

A. Sadollahkhani, O. Nur, M. Willander, I. Kazeminezhad, V. Khranovskyy, M. O. Eriksson, R. Yakimova, and P. O. Holtz Ceramics International 41, 7174 (2015)

XIII. ZnO Films Formed by Atomic Layer Deposition as an Optical Biosensor Platform for the Detection of Grapevine Virus Atype Proteins

A. Tereshchenko, V. Fedorenko, V. Smyntyna, I. Konup, A. Konup, M. Eriksson, R. Yakimova, A. Ramanavicius, S. Balme, and $\mathrm{M}$. Bechelany

Biosensors and Bioelectronics 92, 763 (2017)

XIV. Tuning the Emission Energy of Chemically Doped Graphene Quantum Dots

N. U. Ain, M. O. Eriksson, S. Schmidt, M. Asghar, P. C. Lin, P. O. Holtz, M. Syväjärvi, and G. R. Yazdi

Nanomaterials 6, 198 (2016) 


\section{Papers}

The articles associated with this thesis have been removed for copyright reasons. For more details about these see:

http://urn.kb.se/resolve? urn:nbn:se:liu:diva-139766 